\title{
Exploring Suppliers' Approaches toward Workplace Safety Compliance in the Global Garment Sector: From Bangladesh Perspective
}

\author{
Md Sultan Mahmood *, Nilima Haque Ruma, Toufiq Ahmed (1) and Yukari Nagai *
}

check for

updates

Citation: Mahmood, Md Sultan, Nilima Haque Ruma, Toufiq Ahmed, and Yukari Nagai. 2021. Exploring Suppliers' Approaches toward Workplace Safety Compliance in the Global Garment Sector: From Bangladesh Perspective. Social Sciences 10: 90. https://doi.org/ 10.3390/socsci10030090

Academic Editor: Nigel Parton

Received: 30 December 2020

Accepted: 25 February 2021

Published: 3 March 2021

Publisher's Note: MDPI stays neutral with regard to jurisdictional claims in published maps and institutional affiliations.

Copyright: (c) 2021 by the authors. Licensee MDPI, Basel, Switzerland. This article is an open access article distributed under the terms and conditions of the Creative Commons Attribution (CC BY) license (https:// creativecommons.org/licenses/by/ $4.0 /)$.
School of Knowledge Science, Japan Advanced Institute of Science and Technology, Nomi, Ishikawa 9231292, Japan; ruma18@jaist.ac.jp (N.H.R.); Toufiq30.ku.jp@gmail.com (T.A.)

* Correspondence: sultan@jaist.ac.jp (M.S.M.); ynagai@jaist.ac.jp (Y.N.)

\begin{abstract}
The readymade garment (RMG) sector is one of the main drivers of the Bangladesh economy with over 4 million employed. In the 2013 Rana Plaza accident aftermath, the implementation of workplace safety compliance (WSC) became imperative. The paper investigated the WSC initiatives implemented by the RMG sector to overcome safety challenges and their effectiveness for a safe and healthy workplace. We employed a multi-case study research strategy over three Bangladeshi garment manufacturers to resolve these queries. The result revealed that the manufacturers joined in the safety governance programs to protect workers' health safety rights immediately after the accidents. They participated in inspections and remediations programs over structural, electrical, and fire protection as a priority. Moreover, several other human rights conventions, national labor laws and, buyer code of conduct were also adopted as regulatory and voluntary initiatives to settle workers' health rights and social needs. The WSC enforcement empowered workers to bargain their rights toward a safe workplace and made them responsible for responding during an emergency. Finally, the paper argues that the WSC in the RMG sector nowadays covers a wide range of initiatives in three broad areas: physical environment safety, workers' health issues, and workers' rights.
\end{abstract}

Keywords: sustainability; workplace safety; occupational health; social compliance; Rana Plaza collapsed; readymade garment industry; workplace regulation

\section{Introduction}

Workplace safety compliance (WSC) often denotes the implementation of occupational health and safety (OHS) or health, safety, and wellbeing (HSW) regulations in the work environment. It is very significant for a successful business strategy because the HSW of the employees must carry importance to corporate policy. A good set of WSC policies and practices can bring secondary benefit to firms by protecting coworkers, family members, customers, suppliers, and nearby communities (Robson et al. 2016). Dr. Maria Neria, director of the World Health Organization (WHO), stated that business growth would rely on workers' better health (World Health Organization 2010). The unsafe workplace often causes workers' health suffering such as skin irritation, headaches, fatigue, or stress. Nonetheless, safe work conditions and care for workers' health can refrain them from leaving jobs (Huq et al. 2014). A body of OHS literature claimed the benefits of a safe and healthy workplace (SHW) culture positively influence the workers' physical and mental health and their efficiencies, which subsequently impact the overall productivity of a firm (Morillas et al. 2013; Robson et al. 2016; Harvard T.H. CHAN School of Public Health 2019; Harvey and Gavigan 2014).

The nature of the global garment sector (GGS) is complex and always experiences quick changes concerning marketers' desires. The fashion companies and consumers' fashion appetite in the global north are speeding pressures on the global south factories concerning quickened production changes, tight lead times, overworks, and low-cost 
manufacturing (Taplin 2014). These pressures of the global market often exercise upon the workers in job insecurity, prolonged working hours, and poor health safety (Greet De and Prentice 2017). The long-neglected workplace health manifested two equally alarming directions, such as massive workplace disasters causing injuries and fatalities on the one hand and routine violations of employees' everyday health rights on the other (Prentice et al. 2018). The global south factories always grip attention due to unsafe and poor work conditions regarding building and fire (B\&F) safety and worker's health issues (Ashraf and Prentice 2019).

In the last one and half-decades, the developing countries' suppliers experienced many workplace catastrophes that cost massive deaths and injuries. The Spectrum Sweater factory collapse in Bangladesh in 2005 led to 64 deaths and 80 injuries (BBC 2005). The two mammoth fire accidents, the Ali enterprise fire of Pakistan and the Tazreen factory fire of Bangladesh occurred in 2012. Both fire accidents killed 300 workers in Pakistan and 120 workers in Bangladesh (Nawaz et al. 2019; Greet De and Prentice 2017). Finally, the deadliest workplace accident, the Rana Plaza collapse, took place also in Bangladesh on 26 April 2013, which killed over 1100 and severely injured a hundred more people (Paul and Rocha 2017). The media investigations and academic scholars stated that the mishaps were repeated in the GGS due to substandard B\&F safety standards, inadequate construction inspections and maintenance, and weak workplace regulations.

\subsection{Background of the Research}

The garment sector is one of the economic propellers of Bangladesh, as it contributes above 80 percent of the total exports over the last few decades and has provided over 4 million jobs to the rural people of the country (BKMEA 2018). This sector brought remarkable changes in living standards and empowerment of underprivileged women (Heath and Mobarak 2015). Simultaneously, the sector has been suffering from wideranging allegations toward legal and ethical compliance issues since its beginning (Nasrullah and Rahim 2014). The two worst industrial accidents, the Tazreen fire and the Rana Plaza collapse, depicted the inhumane work conditions and workers' health rights violations worldwide. These accidents stimulated the global buyers, retailers, trade unions, and state regulators to reconsider the WSC of the Bangladeshi RMG sector (Labowitz and Baumann-Pauly 2014; Ashraf and Prentice 2019). Three significant plans, including Accord on fire and building safety (Accord), Alliance for Bangladesh Worker Safety (Alliance), the National Tripartite Plan of Action (NTPA) on Fire Safety and Structural Integrity, began to implement the factory safety assessment and remediations throughout the Bangladesh RMG sector (Labowitz and Baumann-Pauly 2014; Ansary and Barua 2015).

As illustrated above, the pursuit of WSC in the GGS became inescapable after the deadliest disaster in 2013. Accident aftermath, the workplace regulations, and its longterm practices in the GGS sector have been a growing consideration both in practical and academic fields. The past research works asserted that the garment sector, in recent years, brought radical improvements over constructions and building safety, fire equipment, and code of practices for its beneficiaries: workers, shareholders, communities, and customers (Chen 2019; Barrett et al. 2018; Barua and Ansary 2017; Wadud and Huda 2017). Moreover, public and private interventions on workplace safety programs (WSP) forced factories to strictly administer and scrutinize WSC through the lens of legal and regulatory requirements (Ashraf 2017; Sinkovics et al. 2016).

To date, a few studies have seen workplace safety compliance issues that are overgeneralized and do not provide scalable measures from the manufacturers' perspective. More empirical investigations require to address the garment suppliers' approaches on the workplace compliance challenges to sustain in the competitive markets. Abundant literature in OHS or workplace H\&S focused on limited variables of ethical and social compliance practices: work conditions, working hours, low wages, weak governance, absence of association, unions, poor ergonomic design that affect firm's productivity, workers' 
efficiencies, and growth (Morillas et al. 2013; Harvey and Gavigan 2014; Tebyetekerwa et al. 2017; Sorensen et al. 2019; Manu et al. 2018).

Additionally, numerous studies shed light on workplace disasters and their further consequences concerning regulatory reforms in the global supply chain (Labowitz and Baumann-Pauly 2014; Taplin 2014; Jacobs and Singhal 2017), enforceable governance programs (Salminen 2018), labor codes, and OHS rights reforms (Prentice et al. 2018; Greet De and Prentice 2017), human rights violations (Siddiqui and Uddin 2016; Aruna 2019) and workers' compensations and justices (Siddiqi 2015) after Rana Plaza disaster. Several studies have depicted the safety compliance issue of the garment sector from corporate social responsibility (CSR) and social sustainability context (Sinkovics et al. 2016; Haque and Azmat 2015; Huq et al. 2014; Akbar and Ahsan 2019). Again, a few studies have focused on the building and fire assessment and Accord's intervention toward workplace safety (Barua and Ansary 2017; Wadud and Huda 2017). In-depth analysis of WSC and its implementation to improve safe and healthy workplace from suppliers' perspective are still inadequate. This paper endeavored to fix this gap by exploring garment suppliers' approaches toward WSC from the Bangladesh context.

\subsection{Research Aim and Questions}

This paper aims to explore the suppliers' approaches to WSC in the Rana Plaza aftermath. By doing so, we put a few queries to achieve the paper's aim.

(RQ1) What measures do the garment manufacturers implement to combat safety challenges?

(RQ2) How does the Accord's workplace safety program affect the WSC implementation?

(RQ3) How effective the WSC to devise an SHW culture?

The study adopted a case study research strategy on the three Bangladeshi garment suppliers, who are the key competitors of the GGS, to reveal the above queries.

The paper makes four significant contributions to social science research. First, it emphasizes lead suppliers' perceptions in implementing WSC in the production facilities of the developing country's garment sector, which are yet less investigated areas. Second, it renders insights into the realities of implementing WSC in the context of the laborintensive garment sector of Bangladesh. Third, the investigations included the views of the experienced management and non-management employees concerning the benefits of WSC. Finally, the paper delivered lead manufacturers' experiences on the SHW model that are scalable and transferable to the RMG sector and fellow industries. The prior studies often failed to address the above issues.

The rest of this paper is arranged as follows. Section 2 disclosed how unsafe work conditions shed light over the years in the Bangladeshi garment sector. We explained the methods and materials in Section 3 on how case companies were identified and the instrument of data collection and analysis procedures. The results of the significant research aim are discussed in Section 4, answering all research queries. In Section 5, the authors highlighted the scientific contributions that offered a new avenue for future research. Finally, we added concluding remarks and several constraints of this paper that open the space for future improvement in a broader context.

\section{A Brief History of Workplace Safety Compliance in Bangladesh}

Bangladesh sanctioned ILO's seven out of eight fundamental conventions on labor rights, but occupational health safety (OHS) did not include. According to the Bangladesh Institute of Labor Studies, the primary laws related to the OHS of Bangladesh are the Bangladesh Labour Act (BLA) 2006. This legal framework on OHS implies mainly to the workers of industries. However, it does not cover all occupations of the country (BILS 2015). Moreover, many other laws and regulations also have some provisions related to WSC applicable to export-oriented industries and their workers due to the rapid access to the world markets. Significantly, the trade scheme, the Generalized Scheme of Preferences (GSP), 
of the European Union has some provisions for acceptable work conditions concerning labor and human rights, minimum wages, working hours, environmental protection, and OHS (European Commission 2020). The garment sector must comply with these provisions and ILO Core Conventions regarding labor codes and working conditions to access the duty-free export markets of Europe and the USA.

Almost literature argued that manufacturers often overlooked the labor codes and human rights practices that positively influence the SHW (Prentice et al. 2018; Siddiqui and Uddin 2016; Sinkovics et al. 2016; Schüßler et al. 2019). Many other studies claimed the manufacturers' ignorance of legal compliance and ethical business practices lead to workplace accidents (Siddiqi 2015; Taplin 2014; Hasan Ashraf 2017). Moreover, many external factors, such as weak state monitoring, lack of enforcement mechanism, inadequate labor inspectors, and the pursuit of profit by both western retailers, also influenced accidents and occupational health issues in production sites (Labowitz and Baumann-Pauly 2014; Taplin 2014; Greet De and Prentice 2017). The literature and media analyses disclosed many accidents in the RMG sector caused by both internal and external factors. Table 1 shows the workplace accidents from 2005 to the date that resulted in numerous injuries and fatalities. The estimated fatalities in the three different periods are above 1500 . The total deaths and physical injuries during 2012-2013 were five to six times higher than the other two periods because of two devastating accidents.

Table 1. Workplace Fatalities and Injuries in export-oriented Garment Industry of Bangladesh.

\begin{tabular}{|c|c|c|c|c|c|}
\hline Years & $\begin{array}{c}\text { No. of } \\
\text { Occurrences }\end{array}$ & $\begin{array}{c}\text { No. of } \\
\text { Fatalities }\end{array}$ & $\begin{array}{l}\text { No. of } \\
\text { Injuries }\end{array}$ & Reason of Incidents & Major Workplace Accidents \\
\hline $2005-2011$ & $\mathrm{~N} / \mathrm{D}$ & 219 & 324 & Fire and the building collapsed & Spectrum Garment Collapse (2005) \\
\hline 2012-2013 & 63 & 1268 & 3269 & Fire and building collapsed & $\begin{array}{c}\text { Tazreen Fashion Fire and Rana } \\
\text { Plaza Collapse }\end{array}$ \\
\hline 2014-till & 114 & 32 & 235 & Fire and boiler explosion & Multifabs Ltd. Boiler explosion \\
\hline
\end{tabular}

Note: N/D—No data; (Source: Emily 2013; Paul and Rocha 2017; ILO 2017; Solidarity Center 2019).

These accidents occurred after several intervals and stimulated to raise awareness of the social and ethical issues concerning safety, workers' health, and wellbeing issues (Sinkovics et al. 2016; Dana 2019; Jacobs and Singhal 2017). The Rana Plaza collapse emerged as a wake-up call for the poor work conditions faced by workers in the global garment production network (ILO 2017).

The three regulatory bodies emerged in the following months of the Rana Plaza accident in 2013. The Accord by European clothing retailers, Alliance by the United States of America and Canadian fashion companies, and the NTPA on Fire Safety and Structural Integrity by the Bangladeshi Government was formed to push garment factories conducting safety assessments and remediations. Both Accord and Alliance launched individually as a five-year legally independent binding regulator, backed up by global brands, trade unions, and international labor authority (Salminen 2018; Serajul 2019).

The Accord's experts did initial inspections and supervised the constructions' remediations. They forced factories to settle the underlying issues of SEF safety from which their member's buyers source the garments (Jacobs and Singhal 2017; RCC 2015). Accord also emphasized a social compliant mechanism for protecting the workers' OHS rights by creating safety committees (SC) and a safety training program (STP). The promotion of rights to Freedom of Associations, collective bargaining, and anti-discrimination training empowered workers to refuse unsafe work conditions. Again, the NTPA established the Remediation Coordination Cell (RCC) as an individual department that executed the SEF inspections and repairs of the Accord/Alliance excluded garment factories (RCC 2015).

In the Rana Plaza aftermath, the private initiatives, Accord/Alliance, have completed initial inspections above 50 percent of the total garment factories before expirations (DIFE 2019). The Accord handed over the remaining factories to the Government of Bangladesh. The Bangladesh Garment Manufacturers and Exporters Association (BGMEA) launched the 
RMG Sustainability Council (RSC), a tripartite agreement with RCC and Accord/Alliance that acted as a single safety monitoring body of the garment sector (The Daily Star 2019). The RSC put pressure on manufacturers, which already progressed remediations under the private and public programs. Table 2 shows all three plans did initial safety assessment only 3900 out of 4621 factories (as per the BGMEA member list). However, Labowitz and Baumann-Pauly (2015) estimated around 7179 factories, including direct and indirect contractors of garment productions, processing, and exports.

Table 2. Building and fire (B\&F) safety status of the readymade garment (RMG) by three regulators as of August 2018.

\begin{tabular}{cccc}
\hline B\&F Safety Status & Accord & Alliance & NTPA \\
\hline Inspected & 2139 & $672 *$ & 1549 \\
CAP received & 1607 & 672 & 1549 \\
Remediations starts & 1572 & 509 & 809 \\
above 80 percent remediated & 442 & 400 & 218 \\
above 50 percent & 1130 & N/D & 422 \\
No longer covered/suspended/out of scope & $488^{* *}$ & 163 & 39 \\
\hline
\end{tabular}

${ }^{*}$ Note -472 factories out of 672 are also standard in the Accord list; ${ }^{* *}$ Accord handed over 346 factories to NTPA. The rest 142 are non-compliant that terminated business relationships with signatory companies; (Source: Data compiled from from Accord 2019 (as cited in Labowitz and Baumann-Pauly 2014; Ashraf and Prentice 2019; Ansary and Barua 2015), Alliance 2019 (ibid.), DIFE 2019).

By 2019, roughly 1000 factories completed above 80 percent remediation, and around 1500 achieved 50 percent (Table 2) under all three regulators (DIFE 2019). After the expiration of the private regulators, the RSC committed with global brands to continue the residual tasks of WSP. The body took over Accord Building Standard, together with all Accord safety protocols and procedures(DIFE 2019). Currently, inspections and remediation are continuing of all Accord-covered factories against this Building Standard.

Besides WSP, the Ministry of Labor and Employment of Bangladesh also amended the national labor laws of BLA 2006 in 2013 (Abdullah and Mahfuz 2017; BILS 2015) that included many requirements related to OHS. The amendments focused on health and hygiene $(\mathrm{H} \& \mathrm{H})$ provisions, the National Council for Industrial Health and Safety, the mechanisms to solve industrial disputes, labor court, compensation for injury and accidents in the workplace, maternity benefits, factory inspectorate, and safety committee (Government of Bangladesh 2015). Moreover, a range of H\&H requirements included in sections 51 to 60 of the BLA 2006 emphasized cleanliness, ventilation and temperature, dust and fume, disposal of wastes and effluents, artificial humidification, overcrowding, lighting, drinkable water, toilets and washrooms, and dustbin and spittoon (Government of Bangladesh 2015). The acts encouraged employers and workers to make joint efforts to reduce workplace hazards and potential risks by complying with legal provisions.

\section{Methods and Materials}

The paper is one of the key parts of the author's Ph.D. research project on the developing country's garment sector. The research project employed an exploratory case study on the infancy of sustainability research in the context of the Bangladeshi RMG sector. The enabler of safe workplace culture by manufacturers is an essential query of the major research project. Therefore, the current paper used an amount of data from the Ph.D. thesis.

The Bangladeshi RMG industry is crucial to consider as a research context for many reasons. Firstly, the sector is the heart of the national exports and employment generations for underprivileged people, especially women (Heath and Mobarak 2015). Second, the sector often draws attention from global stakeholders because of corporate greed, workers' rights violations, inadequate labor code enforcement, underpaid, unsafe, and unhygienic work conditions (Istiak Ahmed Inam 2019; Prentice et al. 2018). Third, the increased pressures from direct stakeholders such as apparel buyers and employees regarding workplace compliance after the deadly accidents (Sinkovics et al. 2016; Labowitz and Baumann-Pauly 2014). Finally, the sector transitioned to factory safety assessment through public and 
private regulatory governance programs (Accord/Alliance or NTPA). The above reasons offer a rich and dynamic setting for empirical investigations to the researcher.

\subsection{Qualitative Case Study as a Research Strategy}

The exploratory case study was also chosen as a key method in many previous studies of garment manufacturer's social responsibility, workplace safety, and workers' health in developing country perspectives (Sinkovics et al. 2016; Huq et al. 2014; Haque and Azmat 2015). The researcher designed a case study based on qualitative data to investigate the garment suppliers' initiatives that developed throughout the manufacturing supply chain. The key feature of the qualitative data focuses on the naturally occurring and ordinary events in a practical setting (Miles and Huberman 1994). As Yin (2009) suggested, the case study research investigates the details about the studied phenomena and offers the respondents insights about the aspects in a practical setting. The majority of the case research strategy is based on a single case to exploring newly developed topics.

In this paper, we followed a multi-case study approach for selecting three manufacturers from the Bangladeshi RMG sector because of the degree of elaboration and replication among the cases. Eisenhardt and Graebner (2007) mentioned multiple cases to enable a broader exploration of research questions and theoretical elaboration. The conclusions obtained from multi-cases become more potent than those coming from a single-case alone (Yin 2009). Therefore, the paper considered several precautionary measures selecting the three manufacturers by ensuring research quality and consistency. First, all three firms assemble similar products and capable of managing all parts within in-house facilities. Second, as a lead supplier of western clothing brands, all three firms agreed on the workplace safety assessment and remediation. Finally, all case manufacturers are accredited by either the Business Social Compliance Initiative (BSCI) or Supplier Ethical Data Exchange (SeDex) audit requirements (see 'Notes' in Appendix B).

From the researcher's personal experiences and relationship with garment manufacturers, the principal investigator contacted 12 garment suppliers of Bangladesh. Case selection from personal interaction often helps to gain random access to the sites and to contact respondents freely. The researcher sent individual mail with an invitation letter to all twelve suppliers and requested them to participate in the academic research. The letter was explained the researcher's intents, research protocol regarding data collection, analysis, and presentation techniques. Only five manufacturers accepted the researcher's request and cooperated to access the sites with several restrictions based on case firms' corporate policy.

First, an official agreement between the research institution and case organizations. Second, employing a person as responsible to whom the researcher must contact before entering into facilities. Third, all respondents would be contacted through the responsible persons. Fourth, all interviews of the non-management employees must be taken in front of the responsible person. Fifth, one responsible person always give accompaniment during visit all facilities. Sixth, the interview schedules must be informed earlier through email or phone and should not hamper the respondent's assigned jobs. Finally, the interviews could be recorded with participant's consent and the results of the research must maintain company privacy. However, we had to remove two case companies considering the fourth and fifth conditions. Therefore, three manufacturers were selected as case organizations.

\subsection{Data Collection}

The study used a data triangulation technique to gather case study data from various sources. Denzin and Lincoln (2017) suggested that data triangulation would amass the data and information from different sources at different times, places, and persons. The study gathered subjective standpoints from various respondents' categories (see Table 3) through the semi-structured interviews from the three case manufacturers. Respondents from different backgrounds helped us to reach the diversified information from various angles. We conducted in-depth interviews on the 12 respondents from management 
and non-management employees through purposive sampling (Bryman 2012). The case study research often reckons with purposive sampling to reach the targeted respondents who possess sufficient knowledge about the topics and participate in decision making (Saunders et al. 2016).

Table 3. The Profile of Respondents.

\begin{tabular}{cccc}
\hline \multirow{2}{*}{ Respondent Coding } & \multicolumn{3}{c}{ Category of Respondents } \\
\cline { 2 - 4 } & Designation and Job Category & Educational Background & Year of Experience \\
\hline Int.1_C & Senior Manager, Compliance and CSR & MBA & 12 \\
Int.2_B & Chief Operating Officer, Factory Operation & M. Com & 18 \\
Int.3_C & Manager Sustainability & MBA & 13 \\
Int.4_A & Director, Production & Bachelor & 16 \\
Int.5_A & Manager, Compliance & MBA & 14 \\
Int.6_A & Director, Technical and Maintenance & MBBS & 22 \\
Int.7_C & Doctor, Medical Center & MBA & 15 \\
Int.8_B & Senior Manager, Marketing & & \\
Int.9_B & Line Chief, Production (Sewing) & Secondary School & 7 \\
Int.10_A & Supervisor, Production (Fabric) & Secondary School & 6 \\
Int.11_A & Cutting Operator, Production & Primary School & 4 \\
Int.12_C & Asst. Sewing Operator, Production & Primary School & \\
\hline
\end{tabular}

Note-MBA-Master of Business Administration; M.Com.-Master of Commerce, MBBS-Medicine, and Bachelor of Surgery.

In the study, we interviewed 8 top management employees from case organizations who aware of the study contents and able to provide sufficient information (Table 3). Moreover, we also took four non-management interviews, although we expected at least six participants from non-management. We encountered several hurdles concerning data collection from management and non-management employees. First, although we had an agreement, sometimes top management would restrict random access to facilities. Second, management respondents were in a hurry and it was challenging to cover the interview without interruption. Third, participants from non-management often felt shy and afraid of sharing information freely. However, to cope with these challenges, the researchers prepared flexible interview schedules considering times and location. The field data were gathered from respondents in the two different time frames of September-October 2018 and May-June 2019.

From the demographic profile of the respondent, almost all management respondents vastly experience in the garment sector. The minimum qualification of the management employees is a bachelor's degree, and all non-management employees have less than ten years of schooling. The management employee's interviews lasted 60 to 70 min and 40 to 50 min for non-management employees. Almost all discussions during interviews were in the local language (Bangla) and recorded eleven interviews with the consent of participants.

Additionally, the study considered a structured observation (Bryman 2012; Hancock and Algozzine 2006) to gather data through the systematic viewing of the production sites. We took observation notes visiting manufacturers' facilities, including production floors, corporate offices, cafeteria, medical center, and childcare unit. Finally, we focused the document reviews on verifying our understanding of the respondents' feedback. We critically reviewed the internal documents of the company, such as business profiles, audit reports, and the medical center's registry, to get more concrete information. Moreover, some documents related to inspection reports, complaints records, and recognition letters were gathered from external sources. Both documents review helped us aggregate all numeric data regarding companies' financial information, employment size, absenteeism, migration rates, and workers' grievances. We endeavored to minimize social desirability bias (Woodside 2010; Bryman 2012) by pledging interviewees that the study results would be aggregated form. All personal data and company information would remain anonymous. 


\subsection{Data Analysis}

The gathered case study data from purposive sampling are not statistically representative (Saunders et al. 2016). The qualitative data from case studies were analyzed following the interactive model (Miles and Huberman 1994). The analyses consist of the parallel flow activities of the data reduction, data display, conclusion drawing, and verifying (shown in Figure 1). At the first step, the data reduction occurred by summarizing and simplifying the interview data, observation notes, and firms' internal documents. We mainly focused on the essential parts of these sources of data related to the study purpose. The selective data were further displayed through a tabular form, which Miles and Huberman (1994) referred to as matrices. The third set of activities was drawing conclusions and verification of the selected data following the data display. The researchers searched the relationship, patterns, and key categories in the existing data to conclude and parallelly compared the ties among the datasets.

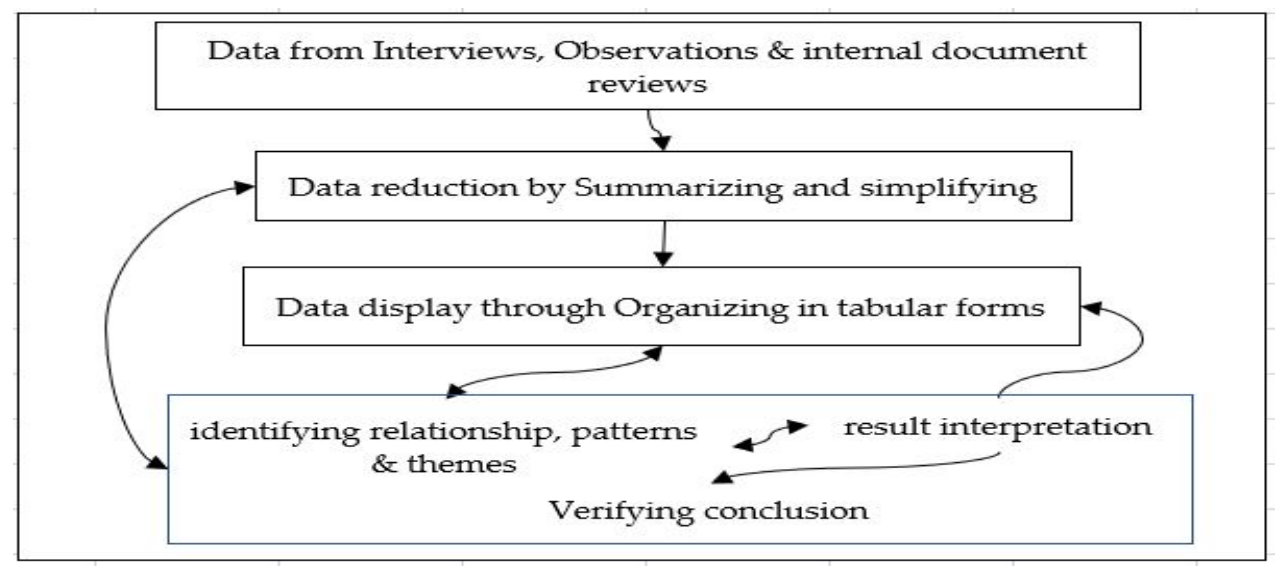

Figure 1. Data Analysis process using an interactive model.

The chosen data from interviews were entered into the appropriate rows and columns cells in the spreadsheet (MS Excel) to segregate the patterns, keywords, and key comments. Further, this step was to relate with observation notes and document summaries. Following data display, the researchers carefully cross-checked the numeric data with companies internal documents produced from interviews. Saunders et al. (2016) argued that data display and analysis offered a set of procedures to the researchers analyzing qualitative data. To ensure internal validity, these three sets of activities adhere to distinguish the whole data analysis process. It is an iterative process (Miles and Huberman 1994; Hancock and Algozzine 2006), and the three steps come into figure consecutively follow each other (see Figure 1).

The study combined the deductive and inductive fashion to interpret the case study and interview data to create new perspectives and understanding. For instance, Saunders et al. (2016) also noticed that the data display and analysis favored an inductive strategy to analyze the qualitative data and compatible with a deductive approach. However, the study interpretation compared the results with previous works to ensure the degree of the external validity of the analysis (Yin 2009). The reproduction of the findings examining the existing literature is pertinent to increase the reliability of this study.

\section{Study Result Analysis}

\subsection{Case Introduction}

All three firms are 100 percent export-oriented composite knitwear manufacturing companies. Firm A is the new generation manufacturer established in 2007 and started commercial operations in the following years. In contrast, the other two firms C and B began their journey as a private limited company in 1987 and 1998. The two firms are 
located at the two crucial industrial zones of the Tongi and Mawna in Gazipur district and another at Fatullah in Narayangonj district. Both firms A and C have three sister-concern under the parent companies, and case $\mathrm{B}$ has two more sister-concern companies under the same group.

All three firms have some similarities and differences concerning ownership structure, employee size, production capacities, annual turnovers, potential clients, and other capabilities. (see the detailed summary in Appendix A Table A1). All three cases belong to the large category in terms of manufacturing operations. The three firms divided their operational activities into Account and finance, supply chain, marketing and merchandising, production, human resources and administration, and research and development departments. Figure 2a presented the employment size of three firms. The total employees of firm B were two times greater than the others. The female employees' percentage of firms A and B are less than 40 percent (shown in Figure 2b), which is significantly lower than the industry average of 75 percent.

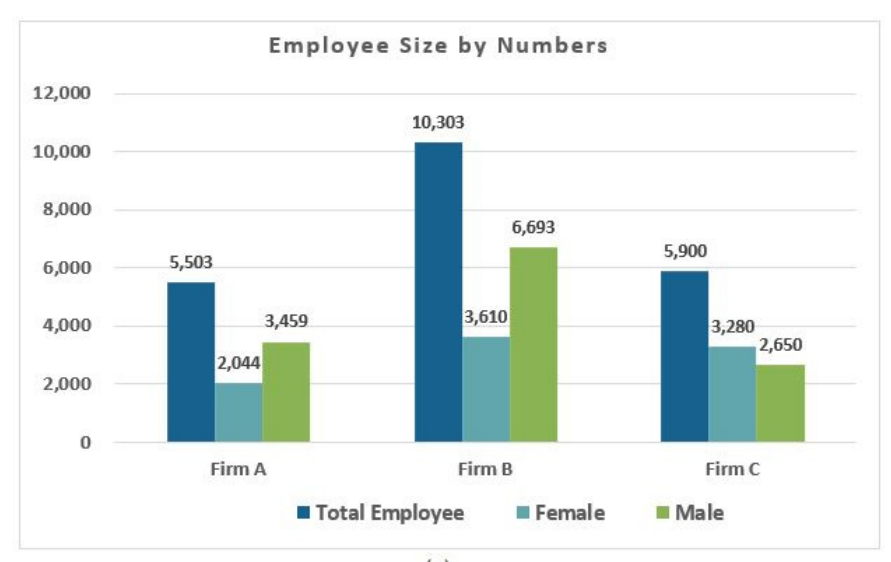

(a)

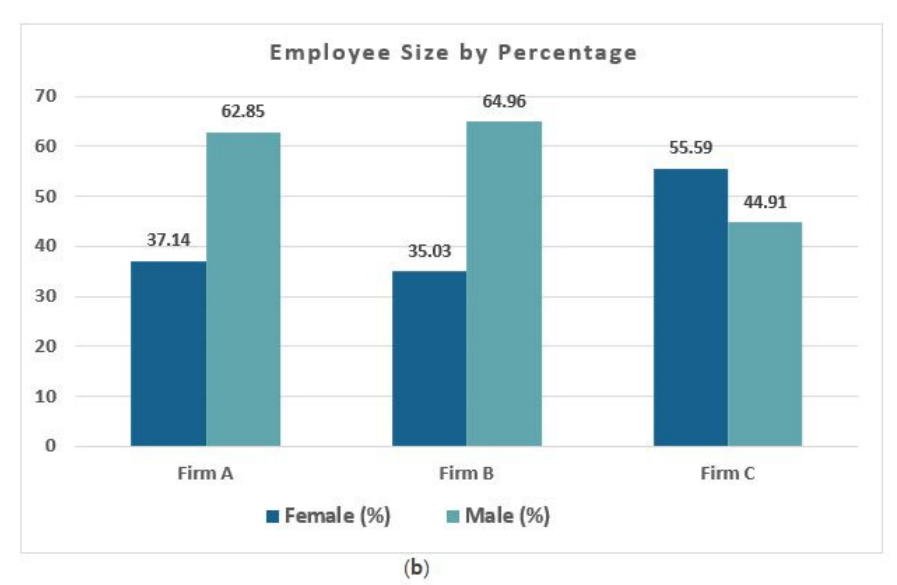

(b)

Figure 2. (a) The total male and female employees of three firms; (b) the ratio of male and female employees.

All three manufacturers have adequate production capacity, with an average of 80 to 120 garment assembling lines (GAL). For firm A and B, each GAL consists of 15 to 20 sewing machines and an average of 18 to 25 sewing operators based on several factors. In contrast, firm $C$ designed above 60 percent GAL for critical garment stitching with an average of 25 to 30 machines and 35 to 40 labors.

As a massive manufacturing operation, all three firms release a substantial amount of emission, wastewaters, chemical, and solid wastes that impact the internal and external environment. All three firms have some similarities concerning production processes, shipping destinations, type of buyer contact, auditing, and accountability requirements with their garment buyers. They do business directly with buyers, and they must approve for BSCI by Foreign Trade Agreement (FTA) as an exporter to the European market. As per social compliance audit results, both firms B and C listed as Rating-A suppliers, and they valued western fashion companies as potential business partners. The manufacturer's relationship with western buyers is more extended periods contrasting with Sinkovics et al. (2016) studied firms.

All three firms' yearly sales quantities and values have been gradually increasing during the last three years, shown in Figure 3a. Nevertheless, the average prices of all three firms gradually decreased in FY 2018-19 than in the past years. The growth rates of firm A and C showed in Figure 3b, are nearly double in FY2018-19 than the previous year. However, firm $B$ experienced a slight decrease during the same period. The annual production capacities of case $B$ are twice that of firm $C$ and almost one-third more than case firm A (shown in Appendix A Table A1). However, the average production process loss of firm B is significantly less than the other two firms A and C, which means the firm is more efficiently use its capacities. 


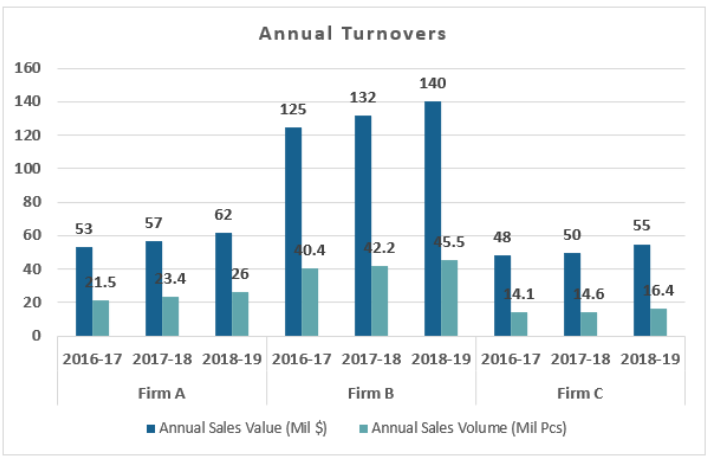

(a)

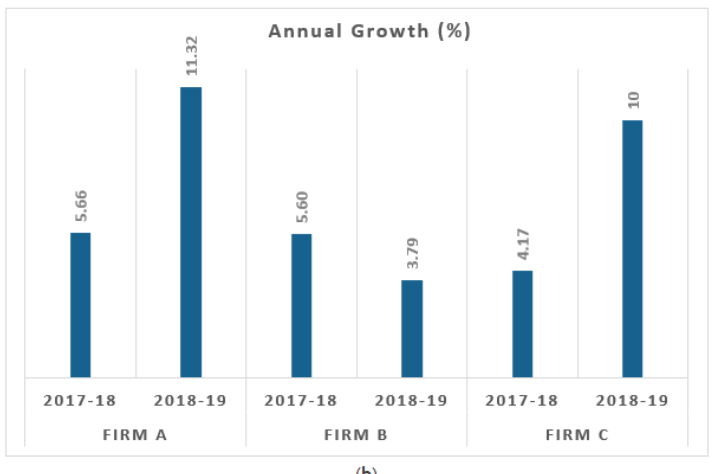

(b)

Figure 3. (a) The annual turnovers in sales volume and values; (b) The annual growth rates in sales value.

The firms met several audit standards of BSCI, SeDex, ISO, and OEKO-TEX (see 'Notes' in Appendix B), concerning the social and environmental pillars. Case $C$ was awarded the Leadership in Energy and Environmental Design (Gold Category) in 2016 for green factory building (GFB). This award certified firm meeting the requirements for energy, water, and waste management efficiency. Both cases A and B adopted the OEKO-TEX STeP and Higg's Facility Environment Module, respectively, to reduce emissions and wastes from facilities' operations. All three firms integrated digital technologies with the building management system (BMS) to control and measure environmental quality (air, temperature, and carbon emissions).

All firms are still struggling to reduce absent rates below 5 percent, shown in Figure $4 \mathrm{~b}$. Still, the job migration rates of case A shown in Figure 4a are higher than the others. Firms $B$ and $C$ documented employees' absent rates of 5.3 and 5.2 percent, respectively, which are the lowest in 2019. However, the job migration rate of these two firms B and C, reduced to 4.9 and 4.2, respectively, in 2019, which is acceptable rates by manufacturers. In contrast, firm $\mathrm{A}$ is experiencing higher absent rates and employee migrations for the last three, comparing the other two firms shown in Figure 4a,b. However, it is gradually improving the annual rates of both categories in 2019 considering the past three years.

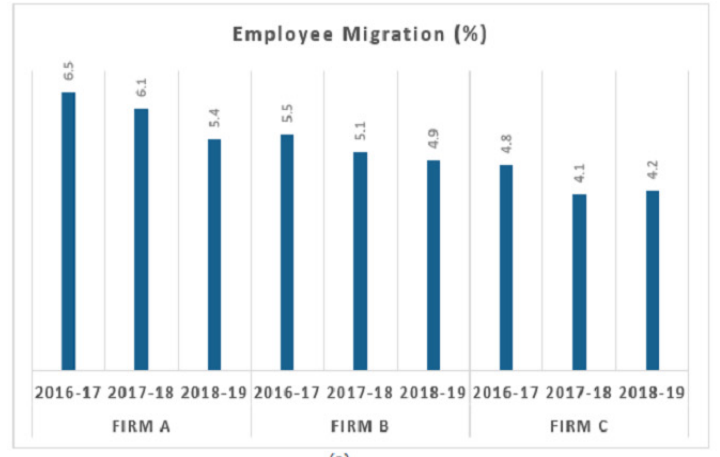

(a)

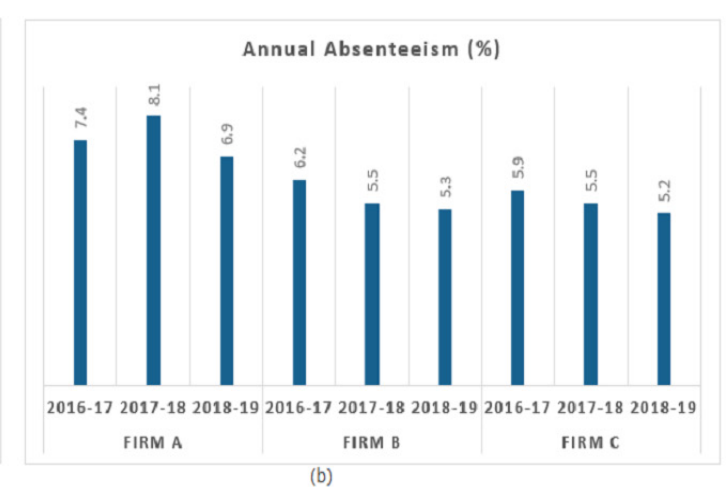

(b)

Figure 4. (a) The job migration rates; and (b) the annual absenteeism rates of three case firms.

\subsection{Workplace Safety Compliance (WSC) Initiatives toward SHW by Case Firms (RQ1)}

The case firms took several core initiatives (CIs) that can be categorized under three key areas: physical environment safety (PES), occupational health $(\mathrm{OH})$, and workers' rights (WRs). The case firms aimed to tackle work-related accidents and health hazards by implementing, monitoring, and practicing a range of enabling measures (EMs) that are described in following sections. 


\subsubsection{Physical Environment Safety (PES) Practice}

The garment suppliers focused on PES as a priority. They joined the private governance program to commence the mammoth tasks of factory safety inspections and remediations. Subsequently, they evolved the chemical safety Management (CSM), and efficient safety management (ESM) to improve the PES, presented in Table 4 . The firms executed various EMs to enhance PES. The implementation approaches of these measures varied concerning firms' financial, operational, and managerial capacities.

Table 4. Physical Environment Safety (PES) initiatives toward workplace safety compliance (WSC).

\begin{tabular}{|c|c|c|c|c|}
\hline CIs & EMs & Case A & Case B & Case C \\
\hline \multirow{3}{*}{ B\&F safety } & Conducted Structural Safety Inspections and Remediation & O & 0 & O \\
\hline & Conducted Electrical and Fire Safety Repairing & $\bigcirc$ & $\bigcirc$ & $\bigcirc$ \\
\hline & Boiler safety inspection by Third Party & $\times$ & $\times$ & $\triangle$ \\
\hline \multirow{5}{*}{ CSM } & $\begin{array}{c}\text { Implementation of the National and International Chemical Regulation (Such } \\
\text { as RSL or MRSL) }\end{array}$ & O & O & O \\
\hline & $\begin{array}{c}\text { Accredited Laboratory facility for chemical assessment and identifying } \\
\text { hazardous substance }\end{array}$ & ○ & ○ & O \\
\hline & Implementing Chemical Management System (such as MSD, PPE) & $\triangle$ & $\bigcirc$ & $\triangle$ \\
\hline & Safe disposing policy (Hazardous and Non-hazardous) & $\triangle$ & $\bigcirc$ & O \\
\hline & Implementing periodic training on CSM & $\triangle$ & O & O \\
\hline \multirow{4}{*}{ ESM } & Installed adequate fire and electrical safety apparatus as per Accord's CAPs & ○ & O & O \\
\hline & Sufficient supply of Personal Protective Equipment (PPE) and First Aid Boxes & $\bigcirc$ & $\bigcirc$ & $\bigcirc$ \\
\hline & Safety Communications System (Announcement, Maps, and illuminated Signs) & $\triangle$ & $\bigcirc$ & $\bigcirc$ \\
\hline & Safety Personnel and Training & $\bigcirc$ & $\bigcirc$ & 0 \\
\hline
\end{tabular}

Note: $\bigcirc-$ Yes, $\times$ 一No; and $\triangle$-Action to be taken.

Building and Fire (B\&F) Safety Initiatives

The first regulatory initiative of the three firms regarding B\&F safety commenced after formal agreement with Accord's initial safety inspections (ISI) over structural, electrical, and fire (SEF). Among the three case organizations, firm C joined in WSP following months after the Accord launched in May 2013. The ISI of the firms identified many safety risks over SEF issues shown in Table 5. The table shows that the number of production constructions belongs to firm $\mathrm{A}$ is twice that of the other two firms.

Table 5. Accord's findings over Structural, Electricity, and Fire initial inspections.

\begin{tabular}{|c|c|c|c|c|c|c|}
\hline \multirow{2}{*}{ Case } & \multirow{2}{*}{$\begin{array}{l}\text { Initial Inspection } \\
\text { Date }\end{array}$} & \multirow{2}{*}{$\begin{array}{c}\text { Total Audited Production } \\
\text { Constructions }\end{array}$} & \multicolumn{3}{|c|}{ Number of Hazards Detected } & \multirow{2}{*}{$\begin{array}{c}\text { Remediation } \\
\text { Completion Date }\end{array}$} \\
\hline & & & Structural & Fire & Electrical & \\
\hline Case A & 16 April 2014 & 19 & 47 & 112 & 141 & 21 Aug 2019 \\
\hline Case B & 30 Aug 2014 & 10 & 19 & 135 & 98 & 8 Aug 2019 \\
\hline Case C & 26 Sept 2013 & 11 & 15 & 105 & 208 & 6 March 2019 \\
\hline
\end{tabular}

Source: Fieldwork 2018-19 (Data compilation from of Accord CAPs of the case companies).

Firm A identified several structural threats in each production construction, almost 1.5 times more than the other two firms. In contrast, firm B encountered immense fire safety risks with an average of 13.5 per building, much higher than firm A and C. Again, firm $C$ encountered an average of 18.91 electrical issues in each building, which has led to worsening conditions comparing the other two firms. The ISI revealed many safety gaps, including the inconsistency between architectural drawings and physical constructions, load plan management, addition and alterations, weak material strength, inadequate emergency escapes, insufficient electrical systems, and lack of fire equipment (see Appendix A Table A2 for more details).

All three firms conducted a detailed engineering assessment (DEA) over structural constructions following the Bangladesh national building codes (BNBC) of 2006. The 
Accord's structural expert and factories' safety engineers reviewed the DEA and approved it with the corrective action plans (CAPs) before remediations. All three firms began the step-by-step repairing and settled many issues over SEF (Appendix A Table A2) that took a period of 4 to 6 years to complete. One interviewee (Int. 1_C) from top management stated that customers' brand reputation and employees' health are a top priority for considering mammoth safety remediation. However, no financial supports received from our business partners. He further phrased, "Accord forced us to do many unnecessary changes and install costly equipment in the series of follow-up inspections and verification".

Regarding remediations progresses, both case firms A and C completed 95 percent retrofitting tasks, and the other firm completed 100 percent as of May 2019 (Appendix A Table A2). Accord's experts verified each correction through follow-up inspections during the remediation periods and listed it as Accord approved factory. The RSC verified the remaining corrections of firms $\mathrm{A}$ and $\mathrm{C}$ after the Accord expires.

Although the three case firms undertook factory safety inspections and remediations, they excluded boiler room safety assessments. The manufacturing operations of all three firms heavily rely on a steam boiler for fabric production such as dyeing, drying, and heating. The weak monitoring in boiler safety leads to workplace accidents or even fatal accidents in the work environment. The RMG sector experienced many fire accidents due to boiler explosions shown in Table 1. In recent years, the case firms started the boiler safety inspections by internal experts who obtained 2nd class operator certificates. However they did not award any third-party certification under regulatory safety program.

\section{Chemical Safety Management (CSM) Initiatives}

All case firms referred to the chemical preparation and application for fabric processing stages, often exposure to human health that causes skin irritation and injuries. Table 4 illustrated several measures adopted by manufacturers for managing chemical substances safely. Broadly, they implemented two critical practices for CSM. First, the regulatory guidelines prevent hazards throughout the production processes, such as inventory, laboratory testing, usage, and disposal. Second, they formed Standard Operating Procedures (SOP) to reduce chemical use and dispose of the following international management standards, such as Restricted Substance Lists (RSL) or Manufacturing Restricted Substance Lists (MRSL). Moreover, all firms comply with European Chemical Regulations such as REACH (Registration, Evaluation, Authorization, and Restriction of Chemicals) test to export garments in the European region.

Case A follows the guidelines of the OEKO-TEX MRSL. In contrast, the other two firms develop the ZDHC MRSL. Following SOP, three firms maintain some similar practices, such as frequent bleaching and antibacterial cleaning in the fabric processing unit to avoid chemical hazards. Moreover, they comply with material safety data sheets, usage of safety wears, goggles, face shields, and gloves as personal protective equipment (PPE) during chemical handling. However, the SOP varies based on the manufacturers' aim and objectives to practice international standards. Firm A devised the global management standards of OEKO-TEX 100 to improve chemical inventory, usage, and waste management. In partnership with the ZDHC MRSL program, firms B and C maintain careful assessments, test the hazardous parameter, Material Safety Data (MSD) sheet, and on-job training during using and disposing of chemicals. One interviewee (Int.2_B) of case B stated that textile processing is chemical-intensive, which discharged hazardous substances into water bodies. The firm is focusing on the use of green chemicals concerning environmental damage and health safety for workers, customers, and local communities. The respondent asserted collaborative actions by the public and private partnership to manage the industrial wastes.

\section{Efficient Safety Management (ESM) Initiatives}

All three firms introduced many reasonably practical measures enhancing efficient safety management (ESM). Firstly, the firms upgraded fire safety apparatus (FSA) and structural modifications to elevate the electrical and fire protection system. The study 
identified that all three firms arranged more or less 30 types of FSA within factory premises (see Appendix A Table A3). Secondly, all employees complied with the correct use of PPE and caring themselves from physical threats while working. The study found the firms emphasized using masks, needle guards, goggles, ear plugs and gloves to the fabric cutting, sewing, dyeing, and printing workers. The firm kept a first aid box on each work-floor to take immediate primary treatment concerning physical injury of cut, burn, or wounded during machine operation.

Third, three firms improved the safety communication system to send messages regarding dangers by central announcement devices, dong bell, and warning signs. Moreover, all firms also rectified the emergency exits, visual maps, and illuminated signs for an easy escape from factories' buildings. Fourth is empowering the safety personnel (SP) by proper safety training and drills. The SP consist of firefighters, rescue and first aid team. All three firms confirmed that they would engage an average of 5 to 6 percent of the total employees as SP. The SP from each floor is also responsible for evacuating workspaces as soon as the accident announcement.

In cooperation with Accord, all three firms provided practical education through a safety training program (STP) that included the correct usage of the PPE, first aid, safety communication system, and the quick escape plan. Case A and C arranged several internal workshops, drills, and training for workers to raise their responsibilities concerning emergency communications, the usage of safety equipment, and personal care while danger approaching. Besides STP, firm B organized several kinds of training by external experts and internal engineering teams to educate employees on responding in an emergency. The respondent (Int.8_B) of firm B stated, "the training and drills help employees to get practical ideas on how to respond in an emergency during any work-related accidents. The company gathers and analyzes workers' response rate for further actions on improving employees' feedback concerning real incidents".

\subsubsection{Occupational Health $(\mathrm{OH})$ Practices}

The case organizations emphasized $\mathrm{OH}$ practices through implementing health and hygiene $(\mathrm{H} \& \mathrm{H})$ measures, hazards and risks assessment (HRA), and healthcare management $(\mathrm{HCM})$. These firms enabled various $\mathrm{OH}$ measures respecting legal provisions and voluntary initiatives, as shown in Table 6.

Table 6. The Occupational Health $(\mathrm{OH})$ practices toward WSC.

\begin{tabular}{|c|c|c|c|c|}
\hline CIs & EMs & Case $\mathbf{A}$ & Case B & Case $\mathrm{C}$ \\
\hline \multirow{8}{*}{$\begin{array}{c}\mathrm{H} \& \mathrm{H} \\
\text { initiatives }\end{array}$} & Performing daily sweeping and washing & ○ & ○ & ○ \\
\hline & Installing artificial tools to control temperature and humidity & 0 & 0 & 0 \\
\hline & Sufficient lighting arrangement for improving visibility & 0 & 0 & 0 \\
\hline & Wastes and effluents treatment to reduce the negative impact of operations & $\bigcirc$ & 0 & 0 \\
\hline & Reduced over-crowding to improve free movements & $\times$ & 0 & $\triangle$ \\
\hline & Pure drinking water arrangement & 0 & 0 & 0 \\
\hline & Separate washroom and toilet for male and female & 0 & 0 & 0 \\
\hline & Environmental monitoring and assessment to control indoor air quality & 0 & $\bigcirc$ & 0 \\
\hline \multirow{5}{*}{$\begin{array}{c}\text { HRA } \\
\text { initiatives }\end{array}$} & Implementing hazards investigations and recording & O & O & O \\
\hline & Implementing the culture of "identifying the sources of hazards" at worksites & 0 & 0 & 0 \\
\hline & Providing periodic training on hazards and risks assessment & $\times$ & 0 & $\triangle$ \\
\hline & Monitoring potential risks in advance and proactive actions for elimination & $\triangle$ & 0 & 0 \\
\hline & Periodic Third-Party Audits & 0 & ○ & 0 \\
\hline \multirow{4}{*}{$\begin{array}{c}\mathrm{HCM} \\
\text { initiatives }\end{array}$} & Access to primary healthcare benefits; & 0 & 0 & 0 \\
\hline & Reproductive health benefits & 0 & 0 & 0 \\
\hline & Access to childcare facilities & 0 & 0 & 0 \\
\hline & Worker's Health Insurance & $\times$ & $\triangle$ & $\triangle$ \\
\hline
\end{tabular}

Note: $\bigcirc$ Yes, $\times$-No; and $\triangle$-Action to be taken. 
Health and Hygiene (H\&H) Initiatives

A set of $\mathrm{H} \& \mathrm{H}$ practices were complied with by the three firms respecting the national laws of BLA 2006, labor regulations of BLR 2015 and integrated with other global social compliance standards. Table 6 represents many H\&H measures practiced by all three manufacturers to prevent frequent physical hazards and workplace accidents. These firms addressed the most health- and ergonomic-related hazards: slip and fall, burn and cuts, suffocation, awkward posture, and musculoskeletal pain. They identified that inadequate cleaning, poor air circulation, visibility, confined space, and wild temperature instigated these hazards. Almost all respondents echoed that the probability of the slip and fall would occur at fabric processing, printing, and laundry section due to wet and slippery floors. Three firms comply with daily housekeeping to keep clean the production floors, staircases, shared spaces, restrooms, and canteen areas. Most notably, fabric dust, debris, chemical dirt, and hazardous fume are the most common health hazards to workers. Therefore, all firms conduct regular vacuum cleaning and sweeping as preventive measures. The production director (Int.4_A) of firm A stated that poor housekeeping often led to workplace accidents of slips and fell as well as ill-health issues. Our company emphasized daily cleanliness with anti-septic detergents in all work floors, toilets, and washrooms.

The case firms B and C firstly modified the work-floor layouts, ventilation, and lighting system as per Accord's corrective actions to increase visibility, ventilation, and humidity control at production sites. Moreover, they implemented the GFB standards following the United States Green Building Codes (USGBC). Both firms focused on light pollution reduction, the maximum use of natural light, increased ventilation, monitoring indoor air quality, moisture, and temperatures. Firm A, on the other hand, installed exhausted fans, cooling pads, and adequate LED lights on each building to improve inside workroom temperatures and air quality and visibility.

All firms have internal audits on the durable materials and waste streams under solid waste management programs. Firm A committed to environmental quality management to reduce the negative impacts following the national environment acts and OEKO-Tex STeP standards (See 'Notes' in Appendix B). The interviewee (Int.5_A) of firm A was clarified that the firm adopted the national laws and regulations to embed the health and hygiene practices with corporate culture. Moreover, they integrated international standards of cleaner production assessment to increase resource efficiency by reducing hazardous wastes and gases from factory operations. On the contrary, the other two firms have EMS following ISO 14001 standards to control and manage solid wastes and wastewater. They perform material quality assessments during inventories and monitor material flows to prevent the waste stream.

Regarding rights to access pure drinking water, all firms arranged filtered drinking water connections in each workroom. Moreover, they made separate washrooms and toilets for male and female employees. Again, three firms placed numerous portable dustbins and sand-filled buckets to keep the workroom and common spaces maintain a neat and tidy environment. Moreover, firm B circulated numbers of colored posters requesting workers to follow the etiquette to avoid throwing spits and dirt here and there.

\section{Hazards and Risk Assessment (HRA) Initiatives}

The three firms devised the different HRA measures shown in Table 6 in preventing the sources of hazards and probable risks at work locations. In cooperation with Accord, the firms developed the HRA method to detect the sources of SEF risks, ergonomic, chemical, mechanical, and biological hazards. Firm A addressed working in fabric processing, rotary printing, and laundry units as the most hazardous locations because of excessive heats, sound, chemical dust, waste, and heavy machinery operations that adverse to workers' health. Firm C identified the workers handling chemical solutions in fabric processing and printing as more vulnerable to ergonomic hazards. The firm applied periodic training, monitoring potential threats, and analysis of work-related risks as proactive measures. In contrast, Firm B focused on regular maintenance works on the boiler, gas generators, 
electricity, machine repairing, waste management, and the onsite construction works because of health and safety (H\&S) issues.

All incidents and harmful actions always record in logs and further analyze the root causes. Case B hired several engineers for SEF and boiler safety maintenance. They provide periodic training to the safety workforce to develop know-how skills to address workplace hazards. On the contrary, the other two firms empowered the compliance team and safety committee to carry forward HRA. Moreover, the line managers and section head responsible for providing on-job training to workers. The workers are taught to respond to physical hazards and prevent themselves by using safety instructions and protective equipment.

The firms are encouraging self-reporting by workers and their frequent communication to superiors regarding potential dangers. The SP further conducts physical visits, review, and set priorities to take corrective measures against problems. If the issues are critical, then immediate contact with the safety engineering team to fix them. Firm B follows the Plan, do Check, and Action (PDCA) cycle to conduct a risk assessment. The other two firms apply the checklists for addressing and recording the sources of hazardous agents (harm to health) throughout factory premises.

\section{Healthcare Management (HCM) Initiatives}

The case firms introduced several voluntary benefits that meet workers' healthcare demands. All three firms introduced primary healthcare (PHC) by establishing an indoor medical center (MC), recruiting professional physicians and nurses, providing free medicines and vaccines for pregnant workers and children. All firms also developed an independent childcare unit to promote female workers. Each firm allows a maximum of two children of an employee whose age less than six years old. Firms organize these facilities voluntarily to improve employees' physical and psychological health in the work environment. The MC of case B has fourteen wards managed by three doctors, three occupational nurses, and two assistants. In contrast, firms A and C have one full-time physician with two occupational nurses for managing firms' PHC facilities.

The MC of all firms usually provides primary treatments for occupational injuries. Moreover, all firms designed to deliver PHC benefits to care workers' daily health issues. The PHC chiefly covers health surveillance through essential diagnosis, treatment, and counseling support for work-related injuries and non-occupational diseases (such as general sickness and non-communicable disease). Besides these, firm B also arranged mental health counseling, child health, and reproductive health supports recently through an external medical team. Regarding personal hygiene supports, firms A and B provide free sanitary napkins to female workers, and firm $C$ provides an allowance to purchase hygiene products. Moreover, firms $\mathrm{B}$ and $\mathrm{C}$ collaborate with non-governmental organizations (NGOs) to raise awareness of female workers against menstruation taboos.

All three firms engaged in various healthcare programs to extend reproductive health and maternal health supports for female workers in cooperation with Bangladesh Knitwear Manufacturer and Exporters Associations and local NGOs. Only firm B commenced the family planning support center since 2017 , which provided reproductive health advice and birth control commodities. Additionally, firm C introduced the annual health checkup and eyecare camp in 2017 for all employees in partnership with two local private medical colleges and NGOs. Again, the firm provides outdoor treatment supports to workers through affiliated local medical colleges. One interviewee (Int.7_C) of case C explained that the company sent the injured workers to local hospitals if an emergency that unable to solve by the internal medical facility. Moreover, in-house health professionals keep all records regarding work-related injury, general sickness, and infectious diseases.

\subsubsection{Workers Rights (WRs) Practices}

The case firms emphasized securing WRs to enhance $\mathrm{OH}$ practices. The WRs practices consist of three core initiatives: human rights and labor code (HR\&LC), ethical and social 
compliance (ESC), and forms of labor and management-based committees (LMCs), as shown in Table 7.

Table 7. Workers' rights (WRs) practices for WSC.

\begin{tabular}{|c|c|c|c|c|}
\hline CIs & EMs & Case A & Case B & Case C \\
\hline \multirow{7}{*}{ HR\&LC } & Grievance mechanism to prevent harassment & $\bigcirc$ & $\bigcirc$ & $\bigcirc$ \\
\hline & Prohibition of forced labors & $\bigcirc$ & $\bigcirc$ & $\bigcirc$ \\
\hline & Surveillance measure against workplace Violence & $\bigcirc$ & $\bigcirc$ & $\bigcirc$ \\
\hline & Anti-Discrimination Policy & $\bigcirc$ & $\bigcirc$ & $\bigcirc$ \\
\hline & Transparent and impartial management policies for grievance & $\triangle$ & $\triangle$ & $\bigcirc$ \\
\hline & Safety suggestion box and anonymous complaints processes & $\bigcirc$ & $\bigcirc$ & $\bigcirc$ \\
\hline & Freedom of association and Rights to collective bargaining & $\bigcirc$ & $\bigcirc$ & $\bigcirc$ \\
\hline \multirow{5}{*}{ ESC } & Adequate Breaks during works & $\bigcirc$ & $\bigcirc$ & $\bigcirc$ \\
\hline & Maternity leave rights and payment & $\bigcirc$ & $\bigcirc$ & $\bigcirc$ \\
\hline & Paid Sick leaves and Annual leaves & $\bigcirc$ & $\bigcirc$ & $\bigcirc$ \\
\hline & Health Insurance Coverage & $\bigcirc$ & $\bigcirc$ & $\bigcirc$ \\
\hline & Employers liability insurance coverage & $\bigcirc$ & $\bigcirc$ & $\bigcirc$ \\
\hline \multirow{3}{*}{ LMCs } & Factory Safety Committee (SC) & $\bigcirc$ & $\bigcirc$ & $\bigcirc$ \\
\hline & Participatory Committee (PC) & $\bigcirc$ & $\bigcirc$ & $\bigcirc$ \\
\hline & Anti-Harassment Committee (AHC) & $\bigcirc$ & $\bigcirc$ & $\times$ \\
\hline
\end{tabular}

Note: $\bigcirc-$ Yes, $\times$-No; and $\triangle$-Action to be taken.

Human Rights and Labor Code (HR\&LC) Initiatives

All three firms took several crucial measures over human rights and labor code practices to uphold the WRs, shown in Table 7. The workers' awareness about their rights helped them to refuse work in harmful conditions. The case organizations are endeavoring to implement grievance mechanisms against unethical issues such as workplace harassment or bullying, discrimination, violence, and forced labor. Firm A developed the disciplinary measures and penalty system such as show-cause, fine, demotion, hold a promotion, and terminations to prevent non-compliant practices (ILO convention \#111). One representative from the top management of firm C directly controls workers' grievance concerning harassment and solve the issues as a priority. They ensured transparent and impartial management to settle all objections immediately after workers' written complaints. They disclose all compliant and non-compliant issues regarding an SHW in external reporting practices: GRI and UNGC COP.

The other firms, A and B, created the Anti-Harassment Committee (AHC) to resolve physical, sexual, or oral harassment issues following the corporate code of practices. Both firms advised employees notifying verbal or written objections to line managers or committee members. The workers of firm B have direct access via email to the head of human resources or compliance manager if necessary. Moreover, all three companies A, $B$ and $C$ put several complaint boxes throughout the factory so that workers can report work-related issues or problems to top management, hiding their identity.

Three firms endeavor to eliminate workplace violence acts such as slapping, pushing, fighting, or pulling off clothes, or robbery at worksites. Firm A has introduced surveillance measures by engaging security personnel and installed security cameras to monitor employees' actions and wrongdoing that adverse work environment security. Again, firm $B$ launched behavioral training and strict punishment measures to prevent workplace violence. Like firm $\mathrm{A}$, case company $\mathrm{C}$ also developed administrative controls and punishments methods to avoid violence and abuse by coworkers or line managers. Moreover, these firms are concerned about forced labor and discrimination because of some unavoidable behaviors and practices that often occurred by coworkers. In the corporate business norms and procedures, all three firms adopted anti-force labor and anti-discrimination policies to promote workers' human rights practices. As per policy, all three firms discouraged discrimination among workers. They also ensured zero-discrimination concerning salaries, 
bonuses, and other benefits. However, firm $C$ recruited some physically-challenged people in clerical positions with equal salaries and benefits. Like case $C$, firm $B$ also determined to hire from their social commitment.

\section{Ethical and Social Compliance (ESC) Initiatives}

Regarding ethical business practices, the firms developed a set of business principles and procedures (see Table 7) following the BSCI codes of conduct (COC) by foreign trade associations (FTA). As a BSCI listed firm, each firm maintains the standard working hours, overtime hours, adequate break-times, paid leaves (both sick and annual), maternity rights, and employer liability program. Garment assembling consists of many repeated jobs and prolonged hours of works. The workers require adequate breaks and holidays to reduce probable ergonomic hazards. Apart from the compulsory 9-h working, the average hours of overtime (OT) of each firm vary based on garment construction, assembling line layouts, use of automation, worker's efficiencies, and shipment pressures. Firm B and C, in recent years, replaced many manuals works by investing in automation and advanced industrial engineering tools. They believed that mechanizing would increase productivity but reduce assistance, excessive working hours, and risky jobs. In contrast, Firm A still relies on manual and semi-auto sewing machines. However, only automation is implemented in cutting and printing sections.

All three firms adopted the maternity rights and were provisioned to pay 16-weeks of maternity leave with a lump sum amount during childbirth following the national labor laws and ILO convention of maternity protection (\#183). Moreover, all three firms allow yearly 14-day paid sick leave and 18-day annual leaves for all employees. The interviewee (Int.11_A) of firm A denounced the formal procedures of granting sick-leave. He later expressed that workers hardly enjoy sick leave because of work pressures and the sick leave approval system. That is why almost times workers absent when they feel unwell rather than prior leave approval.

Regarding employee health expenses, three firms adopted the health insurance policies only for management employees that usually cover the hospitalization and medicine costs. Only firm C provides a subsidy to workers for outdoor treatments in cooperation with two local hospitals. Besides that, all three firms adopted the employer liability insurance policy to compensate medical costs for all workplace accidents.

\section{Labor Management-Based Committees (LMCs) Initiatives}

Three firms created the participatory committee (PC) and factory safety committee (SC) by engaging both workers and management employees to uphold the WRs regarding SHW. According to the national labor laws (section 175), the firm must promote workers' union activities and collective bargaining practices. However, they formed labor-managementbased PC and SC but discouraged workers from joining the registered trade unions. The workers elect a 12-member PC through voting, but the SC members are appointed by PC and top management selection. The PC mainly facilitates the collective communications that ensure useful discussions and resolutions on workers' rights-related claims, needs, and benefits. One interviewee (Int.9_B) of case B expressed that the workers would have rights to the union or any labor associations as per corporate code policies, but top management often discourages to join any registered labor union. They are always encouraged to consider the company's interests first and absorb management decisions.

\subsection{Roles of Accord to Facilitate WSC Implementation (RQ2)}

As discussed, all three case organizations produce and export goods to Accord signatory companies. Therefore, all must participate in Accord's prescribed inspection, remediations, and workplace governance programs. The result already described the Accord contributions to progress building and fire safety measures by case companies. Here, we summarized the Accord's enforceable roles that facilitated case firms to sustain a safe workplace. Case firms received cooperation, guidance, and directions from Accord con- 
cerning structural, electrical, and fire protection issues. Accord inspection and remediation program devoted as an enforcement mechanism to address workplace safety and workers' health in the GGS. All three firms, as players of the GGS, made efforts to develop a safe and healthy workplace for their thousands of workers. However, this private regulator largely concentrated on improving safety in four areas: factory inspections and monitoring remediations, safety committee, safety training, and complaint management.

\subsubsection{Inspections and Remediations}

All three case companies covered by Accord receive SEF initial safety inspections (ISI). The ISI was the first regulatory mechanism that allowed case companies to address structural, electrical, and fire safety issues. The SEF inspections included all production constructions within factory premises and outside constructions that produce for signatory brands. The mandatory inspections began with the structural issue of factory buildings, followed by electrical and fire assessments. As mentioned, case firm A and C owned three sister concerns companies in different business accounts, so that they undertook ISI over SEF safety issues for their factories. In contrast, all business units of case firm B located in single premises and conducted ISI over structural constructions.

The Accord ISI covered minimum life safety issues in SEF safety, respecting widely accepted national and international audit standards. The Accord Building Standard was developed following NFPA codes and the Bangladesh National Building Code (BNBC). These inspection standards are reviewed and approved by Bangladesh Government, national and international safety engineers through ILO supports. After initial inspections, three case firms and the company signatories are tasked with developing a Corrective Action Plan (CAP) that detailed the remedial actions with clear completion timelines.

The Accord monitored remediation progresses through regular follow-up inspections to verify the corrective actions were met correctly. All three firms require a series of follow-up inspections to conform to each correction item. Firm B took almost four years to complete remedy works (see Table 5). The other two firms A and C, have finished all priority repairs and retrofits an average of 3 to 5 years, including modification of building civil works, column stresses load, installation of fire doors, fire alarm systems, and adequate fire exits. Accord engineers physically reviewed and verified all items of the corrective action plan that yielded from repair works. Finally, the factories received approval from the Accord Chief Safety Inspector after correct repairing.

\subsubsection{Empowering Safety Committee}

Accord emphasized a dedicated safety committee (SC) for each factory to carry forward the monitoring and remediation progress. The private regulator forced firms to form labor management-based SC that functions independently to advance the inspection, testing, maintenance of electrical, fire, and structural works. All three firms formed the SC based on equal participation from both management and workers representatives. Accord and the Ethical Trading Initiative (ETI) cooperated with firms to develop the two-long SC through the selection process.

The size of the SC varies among the firms' employee size. All three firms formed an individual SC according to national labor law. Both firms $A$ and $C$ formed a 12-member SC for each factory, but a total of 16-member SC was found for case B. The SC members participated in developing, implementing, and monitoring the factories' property safety and workers' health. In this regard, they became responsible for supervising the SEF safety inspections, remediation works hazards and risk assessment and responding to workers' health issues. Another essential duty of SC is to respond to worker's complaints and suggestions about the work-related hazards and review the workplace accident records on how to prevent them. Firms B and C engaged SC in delivering training to the factory firefighting teams, rescue team, health safety team, and first aid team. The structural and fire safety engineers cooperated with SC to design the training. 
The job duties of SC members also review and evaluate by corporate governance bodies of the three firms. Accord experts taught SC members how to incorporate all issues in a single report and organize review meetings once every three months. The meeting minutes further submit to the top management for their actions wherever necessary and send to Accord (currently RSC) for some instances. The chief operating officer (COO) and compliance head of case B examine the SC activities and thoroughly check the agendas before any workplace safety management decision-making. In contrast, the owner and HR and Admin Director of firm A directly supervise and evaluates the SC activities over factory safety. Again, the Sustainability Head and Welfare manager of case $\mathrm{C}$ generally review and evaluate SC meeting minutes, and further actions took to resolve the problem.

\subsubsection{Safety Education and Training}

Accord cooperated to deliver safety education to all three firms under the Safety Training Program (STP). The STP facilitated firms to develop a safe workforce with adequate technical know-how to monitor the remediation progress and regular maintenance. This training aims to empower workers to address health safety hazards and report to the safety committee. All three firms received STP over a range of technical and management topics, including mechanical, electrical, biological, chemical, motion and workroom environment. The training curricula were designed considering national and international safety standards. The Accord prepared STP's contents using local language and colorful images, maps, and anime characters as if workers can understand easily and quickly.

Accord's trainers coached SC members and other safety personals through the learning by doing approach. It provided eight training sessions and demos to SC members that covered the investigations of infrastructural issues, health hazards, the workers' rights to safe work, and complaint mechanisms. Accord experts taught SC physical investigations techniques to identify the hazards, including nonessential machines, obstacles on the work floors, inadequate ventilation, lighting, fire and electrical maintenance, and housekeeping. The trainers taught workers some practical techniques, such as factory walk-throughs, independent observations, and contacting workers to identify possible hazards. The respondent (Int.3_C) of case Cstated that the training provided a handful of experiences and know-how skills to handle WSC tasks. He added that SC members received training on hazard and risk assessment, remediation monitoring, and educating workers about identifying the physical, chemical and machine hazards at work floors.

After STP sessions, the SC members participated in the informational meeting where they introduced factory workers. The SC members experienced some essential tasks of monitoring, identifying, and managing the follow-up inspections over the remedial works and complaint mechanisms concerning workers' H\&S rights. Finally, Accord facilitated organizing the quarterly meetings of the SC that focused on the active engagement of the SC Co-Chair for follow-up inspections.

\subsubsection{Safety Complaint Management}

The private regulator also emphasized worker empowerment to bargain their rights concerning health safety risks and other issues. Accord signatory brands and unions provide Accord-listed factory workers with a Complaint Mechanism system. The mechanism protects them against harassment, violence and raises concerns regarding health hazards and safety risks. The study has found the top management of all case firms also aware of handling workers' grievances regularly. They took several policies and developed an internal committee to address workers' complaints, shown in Table 7. However, workers have a scope to file their grievances if the factory's management fails to resolve or overlook them.

Accord investigated complaints concerning H\&S through physical inspection or faceto-face interviews with witnesses based on types of grievance. Further, the findings of investigations and corrective actions are declared to all employees at the factory. Workers' complaints that fall outside H\&S remit considered as non-OHS complaints. Accord 
forwarded these issues to brand and labor signatories and factory management. The respondent (Int.9_B) of firm B shared that the company faced some allegations regarding some OHS and non-OHS issues, and workers requested Accord intervention for solutions.

Both cases A and B had a few H\&S complaints issues filed by workers to Accord (see Table 8). To date, the workers of case B submitted seven allegations to Accord's Complaint team, shown in Table 8. Accord had resolved the five issues that fell in the H\&S category, and the rest two forwarded to factory management and signatory companies. Case A had two complaint issues (Table 8) related to OHS that workers alleged, and one issue resolved. However, the other one was dismissed due to the inability to contact the complainant. On the contrary, case $\mathrm{C}$ has no complaints issues regarding OHS and others.

Table 8. Complaints filed in Accord by workers.

\begin{tabular}{|c|c|c|c|c|}
\hline Case & Issues & Complaint Type & Status & Year \\
\hline \multirow{2}{*}{ Case A } & the factory building was unsafe, but no specific reasons & OHS & resolved & Oct-17 \\
\hline & workers are forced to work at the weekend & Non-OHS & unresolved & Oct-17 \\
\hline \multirow{7}{*}{ Case B } & $\begin{array}{c}\text { excessive heat generation due to lack of ventilation at print } \\
\text { shopfloor }\end{array}$ & OHS & resolved & May-17 \\
\hline & Sexual harassment & OHS & resolved & Jun-17 \\
\hline & workers use PPE incorrectly & OHS & resolved & Aug-17 \\
\hline & $\begin{array}{l}\text { the resignation was not allowed by the management due } \\
\text { to high work pressure }\end{array}$ & OHS & resolved & Nov-17 \\
\hline & $\begin{array}{c}\text { prolonged work without breaks and misconduct by floor } \\
\text { managers }\end{array}$ & OHS & resolved & Jan-18 \\
\hline & $\begin{array}{l}\text { non-payment after leaving the factory without informing } \\
\text { factory management }\end{array}$ & Non-OHS & unresolved & Mar-18 \\
\hline & $\begin{array}{l}\text { forced resign due to stealing medical supplies from } \\
\text { factory's medical center }\end{array}$ & Non-OHS & unresolved & Jan-19 \\
\hline
\end{tabular}

Note: Here 'Unresolved' means 'Dismissed' because complainants were unavailable during Accord physical investigation. Source: Data compiled during fieldworks in 2019 and verify with Accord's Complaint Mechanism Records 2019.

\subsection{The Effectiveness of WSC Practices toward SHW (RQ3)}

The WSC implementation and its incessant practices in the garment sector increase immense values in firms' corporate responsibility and accountability. Garment employers and the workers both enjoy benefits from SHW culture. The study results in previous sections have produced lots of evidence on how three case companies stimulated their SHW agendas through implementing WSC initiatives. However, the WSC practices are beneficial in several ways that contribute to devising SHW.

First, the three firms became more transparent and accountable for a safe workplace and worker's safety issues. The Accord's WSP agreed to share all action plans and step-bystep implementation of the safety compliance initiatives. Accord disclosed the factories' safety inspections' findings and remediations progress that pressured firms to settle all corrective actions within timelines. The firms remediated factories' structure, electrical, and fire safety system and installed many electrical and fire equipment to fix the fire protection system. Examples include civil construction works, electrical wiring, egress doors, emergency exits, fire alarms, fire-rated constructions, and evacuation plans. (see Appendix A Tables A1 and A2).

Moreover, three manufactures also adopted the chemical policy and hazard and risks assessment (HRA) following national and international regulations to save workers' lives from physical, biological, and chemical hazards. Accord trainers and the training programs helped manufacturers addressing chemical hazards and creating measures for protecting workers. However, these modernizations have been executing concerning national and international regulations, and standards and these improvements were inspected, tested, and verified by third-party auditors. The technical director (Int.6_A) of case A stated, "the company did lots of repair works to secure workers' lives and improve the good work condition. As an A-grade supplier, we integrated many global standards on social and environmental compliance 
that embedded workers' rights safe work conditions. There is no hide and seek. What we have done already western brands, retailers, and trade unions can easily trace us".

Second, the case firms' WSC also concentrated on workers' physical and mental health by integrating social and ethical business practices. They work out for several $\mathrm{OH}$ initiatives to deliver physical and psychological healthcare supports to workers. The enabling measures of each sub-category of the $\mathrm{OH}$ (shown in Table 6) affect the workers' healthcare demands and work-related injuries. All three case firms focused on improving visibility, ventilation, and humidity control as preventive measures of workplace health and work-related injuries such as slips and falls, inhalation, and vision problems. Moreover, in-house primary healthcare facilities, including medical centers, physicians, occupational nurses, health surveillance facilities, free medicines, and vaccines, ensure the faster services provided to workers' general sickness and daily healthcare. The case firm's external collaboration with local NGOs, hospitals, and industry associations motivates them to engage in various healthcare programs including psychological, and reproductive health.

Third, the WRs practices enhance workers' participation in firms' WSC initiatives. After Rana Plaza's collapse, all three case firms endeavored to extend the labor code practices and human rights conventions from their social and ethical business commitment. They addressed and altered several ethical business practices concerning working hours, overtime works, holiday duties, break times, maternal and sick leaves. Moreover, the impartial and transparent grievance mechanism on harassment, violence, and discrimination across the production floors and management practices encourage workers to voice their voices against coworkers' misconduct. Most importantly, the formation of internal committees such as PC and SC can reconcile workers' $\mathrm{OH}$ and non-OHS rights through collective bargaining with factories' management.

Finally, in recent years, workers are more acknowledged for their health, safety, and human rights because of their increased participation in the WSC implementation. The firms initiatives toward workers' safety became practical by engaging workers in knowledgecreating and sharing (KCS) processes on workplace compliance implementation. Workers were trained and educated on SEF safety monitoring, drills, first aid management, hazards investigations, and reporting through KCS. The respondent (Int.10_A) of case A expressed, "I joined Accord's training on fire hazards and correct actions. It was my first experience participating in the training. I developed a little bit of knowledge to identify the source of fire hazards and how to use equipment to protect ourselves. We often check the basic safety equipment, exit signs, evacuation maps, and exit doors of this floor".

Many workers participated in several training programs through Accord's STP for the very first time. They improved implicit understanding of workplace safety, health safety, and labor rights. Therefore, workers become equally accountable to protect their workplace and lives through responsible behaviors. While functioning consistently, these factors of WSC turned into more transparent and scalable; therefore, an SHW culture can cultivate in firms' corporate practices.

\section{Discussion}

Accord's workplace safety program is the starting point to improve the factories' SEF safety. Nevertheless, manufacturers' WSC initiatives expanded more than SEF safety issues. They focused on an inclusive improvement for SHW, including factories' constructions, safety management, health hygiene provision, chemical policies, hazard and risks assessment, in-house healthcare management, and workers' OHS rights. As a lead supplier of global brands, they often alter and modify their policies, objectives, and action plans according to national and international regulations. Moreover, the lead suppliers are highly connected with their western buyers in the direct sourcing model. For instance, as a direct supplier of the western buyers, the case firms, in this study, must respect buyers' COC and other global standards of ethical business practices (such as BSCI, Sedex, and ISO 9001) to award work orders. The Accord signatories' emphases of the WSC have arisen because of concern over poor working conditions in the GGS context in the Rana Plaza aftermath. 
Thus, the implementation of WSC by case firms can be linked to two broad aspects: regulatory and voluntary practices. A body of literature considered manufacturers' WSC improvement as legal or regulative reform. It became actionable after continuous pressures from private regulators (Accord/Alliance) and their signatory brands and unions (Labowitz and Baumann-Pauly 2014; Barua and Ansary 2017; Hemphill and White 2018; Sinkovics et al. 2016; Salminen 2018). The results of this study are partially consistent with prior findings. As we argued that the implementation of WSC was not just standing on the pillar of legal or regulatory provisions. Its progress encompassed regulative reforms and normative or voluntary requirements of workers' $\mathrm{OH}$ rights and social needs for a decent livelihood. The case firms are continuously expediating their initiatives on improving an environment of workers' collective bargaining and grievance mechanism in routine work hours, adequate breaks, maternity leaves rights, and healthcare.

The results show that the B\&F remediation of all companies was slowly progressed, although the regulatory pressures from signatory brand companies. The Stern Report also noted the slow pace of progression in remediation works by the garment manufacturers based on the Accord-disclosed report (Labowitz and Baumann-Pauly 2015). However, the investigation had a minor focus that the follow-up inspections and costly safety equipment requirements also challenged remediation progress in times. The results find all firms completed remediation works within Accord tenure and belonged to the first group of fully remediated factory lists. The factory safety impressions of these large firms distinguished them from small and medium firms studied by Sinkovics et al. (2016).

In prior literature, the roles of private governance programs were criticized because of their inspection and remediation plans intended to secure factory properties and the supply networks of the signatory brands, and retailers. These issues suppressed workers' OHS rights beyond its expectation (Greet De and Prentice 2017; Prentice et al. 2018). Again, Stern's report in 2014 raised that signatory buyers significantly biased the private regulators, and the provisions met only buyers' agendas in the global supply chain (Labowitz and Baumann-Pauly 2014). These findings could not be refused as global buyers back the remedial plans. However, our findings also illustrated that Accord bridged the paucity between workers and factories regarding grievance management and OHS rights. However, a few previous works recognized Accord/Alliance contributions that created a direct network between global buyers and workers (Salminen 2018).

The compliant factories lead to better protection for workers' lives and personal safety by accessing fire safety equipment and PPE consistent with previous studies (Barrett et al. 2018; Wadud and Huda 2017). The implementation of WSC and its continuous progress facilitated the case manufacturers to increase the SHW culture. The safe work conditions motivate workers to stay safe in current jobs and fewer absents at works. For workers of all case organizations, in 2018-2019, the tendency of job migration and absenteeism is reduced, shown in Figure $4 \mathrm{a}, \mathrm{b}$. The retention rates increased because of many factors, but the compliance standard has significance in encouraging employees. The health safety improvement and workers' OHS rights personal safety reduce workplace accidents and fatalities rates after the Rana Plaza accident (see Table 1). The SHW culture reduced the chance of accident and work injury rates in the RMG sector.

The firms improved WSC practices a lot over the last few years. They combined SEF safety with EMS standards and green initiatives to enhance environmental quality. Again, adopting the GBS and automated BMS enhanced the resiliency within factory infrastructure and decent work culture that meet the ninth goal of sustainable development. With other legal and social standards developed by firms, the EMS plays pivotal roles in controlling workers' $\mathrm{H} \& S$ issues. In contrast to previous studies, we advocate implementing WSC also promotes holistic sustainability practices (Huq et al. 2014; Akbar and Ahsan 2019).

Although case firms put forward much effort to stimulate the SHW, they must go a long way by addressing the implementation challenges. In line with (Anner and Bair 2016), the paper argued that the garment suppliers made significant progress in addressing factory safety, but much of the work remains ahead. The paper observed a few significant 
drawbacks concerning these case firms' workplace safety initiatives, which distinguished the study from other empirical investigations.

First, all three firms excluded the boiler safety assessment as a part of the overall construction safety. The Accord's WSP also had no remarkable efforts on the factory's boiler safety assessment before its expiration on 15 May 2018. Three manufacturers managed the scheduled boiler maintenances by the internal team, but regulatory inspections were yet to include in factories' CAPs. The weak maintenance and mismanagement may lead to explosions from the steam boiler, representing one of the widespread reasons for many fire accidents in the RMG sector. Several accidents occurred in garment factories in the postRana Plaza era because of the steam boiler explosion (Solidarity Center 2019). Therefore, questions remain about the gaps in the factory governance program.

Second, the companies have seen a sloppy monitoring system incapable of applying actionable measures over OHS rights practices throughout production chains. In Prentice et al. (2018) observations, the garment manufacturers less considered the corporate labor code practices in associate with OHS. On the contrary, our findings reveal that lead suppliers are much aware of labor codes and their implementation to uphold workers' rights. However, lack of coordination between higher and middle management people often impede labor code practices in functioning.

Third, under occupational health provision, all three firms implemented a healthcare program for physiological health and medical benefits. Nevertheless, these are still limited in service delivery concerning employees' size and their corporate policies. Except for a few infectious diseases and general ill-health issues, almost all workers hardly receive proper diagnoses and medications. The firms devised indoor medical facilities only to meet the provisions of the national labor acts and philanthropic intents but rarely fulfill the requirements of workers' physical and mental health.

Fourth, they still have gaps in managing PPE and recording hazards. The correct assessment of the workplace hazards by internal efforts is still missing. Most firms occasionally face workers' carelessness to use PPE while handling harmful substances. Three case firms provided training to workers on PPE usage; however, inadequate monitoring by line managers unable to force workers on PPE usage. There needs careful treatment by top management.

Fifth, all three manufacturers focused on reducing overtime work and holiday duties respecting OHS regulations, but this eventually motivated them to gain financial means. They are interested in automatic production machines, advanced industrial engineering tools, and digital technologies to replace human labor wherever possible. Significantly, after the declaration of the fifth national wages package in December 2018, all case firms reduced the assistive works such as helper's recruitment. Improving ethical business practices by cutting overtime hours or shrinking additional earning scopes may stress workers' mental health. Again, firms' rapid automation also leads to an employment crisis that impacts the economic and social lives in the broader context.

\section{Conclusions}

The three manufacturers committed to achieving the goal of WSC, which led them to develop an SHW culture in the post-Rana Plaza era. The result shows that the case firms' WSC stand on the nine core initiatives (CIs) under three dimensions: physical environment safety, occupational health, and workers' rights concerning OHS. Again, the case firms expanded the nine CIs into 44 enabling measures (EMs) to set specific compliant practices. The paper argues that these 44 measures (shown in Tables 4, 6 and 7) are reasonably practicable and implementable to enable an SHW by garment manufacturers. Moreover, labor management-based committees, workers' participation, and knowledge transfer process over WSC lead manufacturers to embed the SHW culture. However, these measures are essential to devise SHW but are not limited. The manufacturers may adopt many new measures in the changing environment and times to combat new challenges. 
The current model of SHW developed by case firms can transfer to the whole garment sectors in developing countries for creating a safe workplace and saving workers' lives.

All enterprises in the RMG sector must ensure the SHW to sustain in competitive export markets. After private and public regulatory oversight in the post-Rana Plaza era, the internal work conditions and workers' rights practices of the garment sector became much accountable. Moreover, global pressure groups such as trade unions, ILO, NGOs, and other activists are always watchful regarding health safety matters and put pressure whenever necessary. Therefore, the manufacturers' actions in implementing WSC are more transparent than in the previous decade. Nowadays, western brands can easily track suppliers' WSC status and verify them before enlisting as new vendors. The paper discussed still many garments manufacturers yet to complete above 50 percent remediations as per the Accord list. The SHW culture of this paper can provide the guidelines to the garment manufacturers who skipped or ignored to join safety inspections and yet to finish the SEF remediations. Moreover, these results can deliver essential policies to develop safety compliance that is reasonably practicable to subcontractors, the backward linkage sector, and other fellow industries.

The study also faced several constraints. First, the case study method as a research strategy is often criticized due to reliability and theoretical contribution to knowledge. Here, the paper focused only on the composite knitwear manufacturers as a case study, representing only 50 percent of the total RMG exports. Therefore, the study results on the limited cases might not signify the whole RMG sector. However, the knitwear sector has more diversifications than woven concerning manufacturing operations. Moreover, our selected three case organizations fell in direct exporter categories, so the results may not replicate for subcontracting firms or indirect suppliers.

Second, the critical challenge of qualitative research is to prove reproducibility and internal validity based on a small sampling. However, the respondents' size is only 12 , which may not replicate the impression of the whole population. However, the experienced respondents are purposely chosen as they have obtained adequate knowledge on the issues so that their valuable insights spark the real events embedded in the real-life setting.

Third is the restrictions of random visits inside facilities and the access limitations to interviewees. To avoid this, we developed a rapport with three factories' key informants and used a consent form to gather interviews with prior approval from respondents. The fourth is the limited sources of OHS data from manufacturers. The firms record health hazard and accident data in different logs, and they hardly compile it in a single database. It is not easy to get official OHS data from factories. Therefore, we excluded discussing how SHW culture influences the overall occupational accidents or ill-health issues.

The study supports future studies in two directions. First, it offers an extensive view of the manufacturers' approaches in executing the enabling measures toward SHW agendas that redirect sustainable growth. Second, the said limitations guide future research to overcome the boundary of data sources and the subject matters that are overlooked due to the constraint of limited case organizations.

Author Contributions: Conceptualization, M.S.M.; methodology, M.S.M., N.H.R., and T.A.; validationM.S.M., N.H.R., T.A., and Y.N.; formal analysis-M.S.M. and N.H.R.; investigation- M.S.M.; data curation- M.S.M., N.H.R., and T.A.; writing-M.S.M.; writing-review and editing-M.S.M., T.A. and Y.N.; supervision- Y.N. All authors have read and agreed to the published version of the manuscript.

Funding: The author utilized lab budgets and research's own finances to conduct data collection from the field.

Institutional Review Board Statement: Not applicable for studies not involving humans or animals. Informed Consent Statement: Informed consent was obtained from all subjects involved in the study.

Data Availability Statement: The data used in this study are not publicaly available due to participants and case companies privacy. 
Acknowledgments: We acknowledge valuable supports from Shahin, Shibly, and Azad during our fieldwork. Their effortless cooperation throughout the data collection help researchers to access the respondents whenever necessary. Moreover, we thanked two assistances, Sudipta Das Gupta and Maliha Samiha Zaman, graduate students of Shahjalal University of Science and Technology, Sylhet, Bangladesh, for their tremendous support during data gathering in the second phase. Lastly, we are grateful to two anonymous reviewers whose worthy comments and queries supported the authors' rearranging of the paper.

Conflicts of Interest: The authors declare no conflict of interest.

Appendix A

Table A1. The business profiles of the three cases.

\begin{tabular}{|c|c|c|c|}
\hline Features & Case A & Case B & Case C \\
\hline Establishment & 2007 & 1998 & 1987 \\
\hline Facility Location & Mawna, Gazipur, Bangladesh & Narayangonj, Bangladesh & Tongi, Gazipur, Bangladesh \\
\hline Total Business Units & 7 & 3 & 9 \\
\hline Firm Structure & Private Ltd. Company & Private Ltd. Company & Public Ltd. Company \\
\hline Firm capabilities & $\begin{array}{l}\text { fabric mill, laundry, rotary } \\
\text { and screen printing, } \\
\text { embroidery, and cut and sew }\end{array}$ & $\begin{array}{l}\text { fabric mill, laundry, screen } \\
\text { printing, embroidery, and cut } \\
\text { and sew }\end{array}$ & $\begin{array}{c}\text { Fabric mill, laundry, screen } \\
\text { printing, embroidery, and cut } \\
\text { and sew }\end{array}$ \\
\hline Assembling lines * & 100 & 140 & 72 \\
\hline Production Capacity * & $32 \mathrm{mil} \mathrm{pcs/yearly}$ & $50 \mathrm{mil} \mathrm{pcs/yearly}$ & $25 \mathrm{mil} \mathrm{pcs/yearly}$ \\
\hline Prod. Process Loss & Avg. 5 percent & Avg. 3-4 percent & Avg. 6-7 percent \\
\hline Major Customers & $\begin{array}{l}\text { H\&M, Mango, Orsay, Next, } \\
\text { Uneek, 4F }\end{array}$ & $\begin{array}{c}\text { H\&M, C\&A, Primark, s.Oliver, } \\
\text { Esprit }\end{array}$ & $\begin{array}{c}\text { El Corte Ingles, Lindex, } \\
\text { KappAhl, Celio, Sports master }\end{array}$ \\
\hline Product Categories & $\begin{array}{l}\text { Tee, Polo, blouse, and } \\
\text { Sportswear }\end{array}$ & $\begin{array}{l}\text { Basic and casual knitwear for } \\
\text { men, women, and kids }\end{array}$ & Casual, Sportswear, and fancy \\
\hline Compliance Status * & BSCI Rating B & BSCI Rating A & BSCI Rating A \\
\hline Accord's WSP Status & $\begin{array}{l}\text { Almost } 95 \text { percent of } \\
\text { remediation completed }\end{array}$ & $\begin{array}{l}\text { Almost } 100 \text { percent } \\
\text { remediated }\end{array}$ & Above 95 percent remediation \\
\hline $\begin{array}{c}\text { Social and Environmental } \\
\text { Audit Standards }\end{array}$ & $\begin{array}{l}\text { SeDex, ISO9001, Oeko-Tex } \\
\text { STeP, Oeko-Tex 100, }\end{array}$ & $\begin{array}{l}\text { ISO9001, ISO14001 and } \\
\text { OHSAS 18001, Higgs-FEM }\end{array}$ & $\begin{array}{l}\text { SeDex, ISO9001, ISO14001, } \\
\text { LEED, and UNGC COP }\end{array}$ \\
\hline Reporting Practices & Internal & Internal & GRI and Credit Rating Report \\
\hline
\end{tabular}

Notes: * the annual data and information will vary. Source: Data compiled from fieldwork 2018 and 2019 of case organizations in Bangladesh. 
Table A2. Safety hazards and Corrective Actions toward SEF risks.

Dimensions

Structural Hazards

All three firms reproduced the load-plans, and the Accord experts accepted the load-plans along with the DEA report. The firms posted the load-plans on each

Lack of management load plan and incorrect implementation of the existing load management plan

Inconsistency between building constructions and drawings

Lack of design check against lateral load

Poor maintenance and durability

Lack of structural assessment

Addition and alterations mismatch with structural drawings

weak material strength

floor for monitoring floor-wise live load. Factories

ensure occupying the floor under the approved load-plan. Moreover, they corrected the adequacy of columns for supporting loads.

Three firms revised drawings to reflect the as-built structure and to include the planned remedial works following this review

They reviewed the capacity of the large brick wall panels, columns, and beams to resist the wind and lateral loads

Prepare periodical maintenance plans and records all safety hazards observed and remediations steps for improving building durability

all productions building completed the detailed engineering assessment (DEA) before remediations. Firms agreed to conduct the DEA every five years

the numbers of additional productions constructions corrected respecting the national building codes and Accord's CAPs

Factories replaced constructions materials and agreed to use the quality raw materials from nominated material suppliers;

Thermographic scanning (TGS) has not been tested and recorded

factories committed the TGS of the entire electrical system would perform a bi-annual basis and record the test results

organized all the cables or wires securely and neatly. Firm $C$ used a cable ladder to latch the wires on it. All

Lack of cable support and protection three firms replaced old wires with fire-rated cables to protect sparking

Lack of Lightning Protection System (LPS)

Electrical Hazards
Factories installed LPS for all production floors. Accord inspectors reviewed the LPS design before starting installation by factories.

Both cases $\mathrm{A}$ and $\mathrm{C}$ replaced combustible material with the metallic plate (checkered/non-checkered), but case $\mathrm{B}$ used a concrete slab as a cover to protect the cable.

Both factories $\mathrm{A}$ and $\mathrm{B}$ adjusted the main CBs per cable current ampacity/load current. Firm $C$ replaced $\mathrm{CB}$ with the new one.

Hazardous accumulation of dust and lint on electrical equipment

All three firms removed harmful dust and lint on the machines and developed regular maintenance measures once' every two months.

all three firms used the metal casing for the main earthing terminal and resized the earth continuity conductor following BNBC 2006 
Table A2. Cont.

\begin{tabular}{|c|c|c|}
\hline Dimensions & Hazards Identified & Corrective Actions \\
\hline \multirow{7}{*}{ Fire Safety Hazards } & $\begin{array}{l}\text { Inadequate fire detection and alarm } \\
\text { system for all three firms }\end{array}$ & $\begin{array}{l}\text { All three firms re-configured the fire detection and } \\
\text { alarm system following the NFPA-72 and Accord's } \\
\text { guidelines. }\end{array}$ \\
\hline & Inadequate fire suppression system (FSS) & $\begin{array}{l}\text { all firms developed the new FSS to detect fires at the } \\
\text { beginning stages through heat, smoke, and other } \\
\text { warning signals. }\end{array}$ \\
\hline & $\begin{array}{l}\text { Lockable/collapsible gates have found in } \\
\text { all three case firms }\end{array}$ & $\begin{array}{l}\text { all three firms removed all collapsible or lockable gates } \\
\text { and installed fire doors }\end{array}$ \\
\hline & $\begin{array}{l}\text { Inadequate sprinkler and lighting have } \\
\text { identified in all three firms }\end{array}$ & $\begin{array}{c}\text { installed automatic sprinkler throughout the factories' } \\
\text { buildings following NFPA-13. They provided a } \\
\text { minimum illumination of } 10 \text { lux at the floor level } \\
\text { within exit stairs and exit discharge paths and a } \\
\text { minimum of } 2.5 \text { lux along exit access aisles. }\end{array}$ \\
\hline & $\begin{array}{l}\text { Lack of fire separation in hazardous areas } \\
\text { of all three firms }\end{array}$ & $\begin{array}{c}\text { For both firms B and C, the combustible storage } \\
\text { separated by fire-rated constructions, and firm A } \\
\text { newly constructed the fire-coated fences }\end{array}$ \\
\hline & $\begin{array}{l}\text { Non-compliant exit stair openings have } \\
\text { seen in case firm A and C }\end{array}$ & $\begin{array}{c}\text { Both firms A and C modified exit stairs to discharge } \\
\text { directly outside and installed 2-h fire-rated door. Firm } \\
\text { B, seal all unprotected openings to separate the exit } \\
\text { stairs from work areas and installed 1.5-h rated } \\
\text { self-closing fire doors }\end{array}$ \\
\hline & $\begin{array}{l}\text { Inadequate means of egress of all three } \\
\text { firms }\end{array}$ & $\begin{array}{l}\text { All three firms replaced all sliding doors along with } \\
\text { the means of egress with side-hinged and swinging } \\
\text { egress doors. Again, firm C installed a particular door } \\
\text { locking feature complying with NFPA } 101 .\end{array}$ \\
\hline
\end{tabular}

Note: NFPA—National Fire Protection Association; Source: Raw Data gathered and complied from Accord's CAPs of the case organizations.

Table A3. Fire Safety Apparatus installed by three case organizations.

\begin{tabular}{|c|c|c|c|}
\hline \multirow[b]{2}{*}{ Equipment } & \multicolumn{3}{|c|}{ Status of the Fire Safety Apparatus } \\
\hline & Case A & Case B & Case $\mathrm{C}$ \\
\hline $\begin{array}{c}\text { Fire Extinguisher: } \mathrm{CO}_{2} \text {, Dry Powder, and Foam type } \\
\text { Hosepipe: } 65 \mathrm{~mm}, 38 \mathrm{~mm} \text {, and } 25 \mathrm{~mm} \\
\text { Fire protected Helmet } \\
\text { Gas Mask } \\
\text { Hand Gloves } \\
\text { Fire Blanket, hook and Bitter } \\
\text { Spade } \\
\text { Fire Bucket and bucket Stand } \\
\text { Water Drum } \\
\text { Stretcher } \\
\text { Fire Alarm and Siren } \\
\text { Lock cutter } \\
\text { Manila Rope } \\
\text { Fire safety Boot } \\
\text { Fire Safety Harness } \\
\text { Fire Equipment Box } \\
\text { Fire Emergency light } \\
\text { Fog light } \\
\text { Smoke Detector } \\
\text { Smoke Control Panel } \\
\text { Automatic Sprinkler System } \\
\text { Fire Rated Doors }\end{array}$ & $\begin{array}{l}0 \\
0 \\
0 \\
0 \\
0 \\
0 \\
0 \\
0 \\
0 \\
\times \\
0 \\
0 \\
0 \\
0 \\
0 \\
0 \\
0 \\
0 \\
0 \\
0 \\
\times \\
0 \\
0\end{array}$ & $\begin{array}{l}0 \\
0 \\
0 \\
0 \\
0 \\
0 \\
0 \\
0 \\
0 \\
0 \\
0 \\
0 \\
0 \\
0 \\
0 \\
0 \\
0 \\
0 \\
0 \\
0 \\
0 \\
\times \\
0 \\
0\end{array}$ & $\begin{array}{l}0 \\
0 \\
0 \\
0 \\
0 \\
0 \\
0 \\
0 \\
0 \\
0 \\
0 \\
0 \\
\times \\
0 \\
0 \\
0 \\
0 \\
0 \\
0 \\
0 \\
0 \\
0 \\
0\end{array}$ \\
\hline
\end{tabular}




\section{Appendix B}

Notes:

BSCI-Business Social Compliance Initiative was established by amfori in 2003. Its Code of Conduct includes 11 fundamental principles concerning labor standards of the International Labour Organization, UN Charter of Human Rights, and other key international and national regulations in the human rights sphere. (https://www.amfori.org/ content/amfori-bsci accessed on 28 February 2019).

BLA 2006-An Act to consolidate and amend the laws relating to the employment of labor, relations between workers and employers by Ministry of Labor and Employment, Government of Bangladesh. It covered a range of issues, including minimum wage, payment of wages and compensation for injuries to workers, the formation of trade unions, raising and settlement of industrial disputes, health, safety, welfare, and working conditions of workers, and apprenticeship and matters ancillary thereto. (http:/ / www.dol.gov.bd/ site/view/legislative_information/ accessed on 5 May 2020).

DEA-is a detailed structural engineering investigation and reporting of a building structure. It is necessary when there are insufficient information and documentation on the building structure to determine the safety of the structure. (https://dife.portal.gov.bd/ site/page/38da41f2-39b8-42b4-bcd4-c46107e75137 accessed on 26 August 2019).

GSP-Generalized Scheme of Preferences European Union accepts products coming into the EU market without import duties from vulnerable developing countries. (https:// ec.europa.eu/trade/policy/countries-and-regions/development/generalised-scheme-ofpreferences accessed on 12 October 2020).

Higg FEM - stands on Higg Facility Environmental Module, which has several versions developed by Sustainable Apparel Coalition, is a suite of self-assessment tools to assess its environmental impact and performance assessment for sustainable development.

ISO 9001 - refer to the international standard that specifies requirements for a quality management system (QMS). (https:/ / asq.org/quality-resources/iso-9001 accessed on 19 December 2019).

ISO14001-is the international standard that specifies requirements for an effective environmental management system (EMS). (https:/ / asq.org/quality-resources/iso-14001 accessed on 19 December 2019).

LEED—stands on Leadership in Energy and Environmental Design that provides a framework for healthy, highly efficient, and cost-saving green buildings. (https: / / www. usgbc.org/leed/why-leed accessed on 13 November 2018).

MRSL-It is a list of hazardous substances banned internationally in the textile or fabric production processes. (https://mrsl.roadmaptozero.com/ accessed on 15 October 2020).

NFPA-National Fire Protection Association was established in 1896 to reduce fatalities, injury, property, and economy from fire and electrical hazards. It developed almost 300 consensus codes and standards to save lives and reduce loss with information, knowledge, and passion. (https:/ / www.nfpa.org/About-NFPA/NFPA-overview accessed on 18 October 2020).

Oeko-Tex-is a registered trademark representing the product labels and company certifications issued and other services provided by the International Association for Research and Testing in the Field of Textile and Leather Ecology. (https: / www.oeko-tex. $\mathrm{com} /$ accessed on 25 June 2020).

STeP Oeko-Tex-is a worldwide certification system for environmentally friendly and socially responsible production facilities in the textile and clothing industry. (https: / / www.oeko-tex.com/en/our-standards/step-by-oeko-tex accessed on 25 June 2020).

SEDEX - is abbreviated as Supplier Ethical Data Exchange. It is one of the world's leading ethical trade membership organizations, working with businesses to improve working conditions in global supply chains. (https:/ /www.sedex.com/about-us/ accessed on 15 October 2020). 


\section{References}

Abdullah, Mir, and Al Mahfuz. 2017. OHS Provisions at Bangladesh Labor Law 2006 (Amendment 2013). Textile Today, June 15.

Akbar, Suraiyah, and Kamrul Ahsan. 2019. Workplace Safety Compliance Implementation Challenges in Apparel Supplier Firms. Journal of Cleaner Production 232: 462-73. [CrossRef]

Anner, Mark, and Jennifer Bair. 2016. The Bulk of the Iceberg: A Critique of the Stern Center's Report on Worker Safety in Bangladesh. Pennsylvania: Center for Global Workers' Rights (CGWR).

Ansary, Mehedi Ahmed, and Uttama Barua. 2015. Workplace Safety Compliance of RMG Industry in Bangladesh: Structural Assessment of RMG Factory Buildings. International Journal of Disaster Risk Reduction 14: 424-37. [CrossRef]

Aruna, Kashyap. 2019. Paying for a Bus Ticket and Expecting to Fly: How Apparel Brand Purchasing Practices Drive Labor Abuses. New York: Human Rights Watch.

Ashraf, Hasan. 2017. Beyond Building Safety: An Ethnographic Account of Health and Well-Being on the Bangladesh Garment Shop Floor. In Unmaking the Global Sweatshop: Health and Safety of the World's Garment Workers, 1st ed. Edited by Rebecca Prentice and Greet De Neve. Philadelphia: University of Pennsylvania Press, pp. 250-90.

Ashraf, Hasan, and Rebecca Prentice. 2019. Beyond Factory Safety: Labor Unions, Militant Protest, and the Accelerated Ambitions of Bangladesh's Export Garment Industry. In Dialectical Anthropology. Heidelberg: Springer. [CrossRef]

Barrett, Paul M., Dorothée Baumann-Pauly, and April Gu. 2018. Five Years After Rana Plaza: The Way Forward. New York: NYU Strern Center for Business and Human Rights, pp. 1-29.

Barua, Uttama, and Mehedi Ahmed Ansary. 2017. Workplace Safety in Bangladesh Ready-Made Garment Sector: 3 Years after the Rana Plaza Collapse. International Journal of Occupational Safety and Ergonomics 23: 578-83. [CrossRef] [PubMed]

BBC. 2005. Bangladesh Search for Bodies Ends. Available online: http://news.bbc.co.uk/2/hi/south_asia/4737187.stm (accessed on 19 June 2019).

BILS. 2015. Occupational Safety and Health in Bangladesh:National Profile. Dhaka: Bangladesh Institute of Labour Studies, vol. 11.

BKMEA. 2018. Apparel Export Statistics of Bangladesh. Edited by Fazlee Shamim Ehsan. Dhaka: The Research \& Development Cell/BKMEA, Available online: https://goo.gl/smEEcV (accessed on 20 October 2019).

Bryman, Alan. 2012. Social Research Methods, 4th ed. New York: Oxford University Press Inc.

Chen, Michelle. 2019. 6 Years After Rana Plaza Collapse, an Accord to Improve Bangladesh's Worker Safety Is in Jeopardy. Available online: inthesetimes.com/working/entry/21797/accord-rana-plaza-collapse-bangladesh-workers-garment-fashion-government (accessed on 15 February 2020).

Dana, Thomas. 2019. Fashionopolis: The Price of Fast Fashion and the Future of Clothes, 1st ed. London: Penguin Press.

Denzin, Norman K., and Yvonna S. Lincoln. 2017. The SAGE Handbook of Qualitative Research, 5th ed. Thousand Oaks: SAGE Publications, Inc.

DIFE. 2019. Status of Safety Assessment and Remediation. Department of Inspection for Factories and Establishments. Available online: http:/ / database.dife.gov.bd/index.php (accessed on 26 August 2019).

Eisenhardt, Kathleen M., and Melissa E. Graebner. 2007. Theory Building from Cases: Opportunities and Challenges. Academy of Management Journal 50: 25-32. [CrossRef]

Emily, Y. 2013. Bangladesh Textile Workers ‘Deaths' Avoidable. BBC, April 26. Available online: bbc.com/news/business-22296645 (accessed on 15 June 2019).

European Commission. 2020. Joint Report to the European Parliament and the Council Report on the Generalised Scheme of Preferences Covering the Period 2018-2019. Brussels. Available online: https://trade.ec.europa.eu/doclib/docs/2020/february/tradoc_1586 19.pdf (accessed on 10 April 2020).

Government of Bangladesh. 2015. Bangladesh Labor Act 2006. Available online: http://www.dpp.gov.bd/upload_file/gazettes/14212_ 75510.pdf (accessed on 5 May 2020).

Greet De, Neve, and Rebecca Prentice. 2017. Introduction: Rethinking Garment Worker's Health and Safety. In Unmaking the Global Sweatshop: Health and Safety of the World's Garment Workers. Edited by Neve Greet De and Rebecca Prentice. Philadelphia: University of Pennsylvania Press, pp. 1-28.

Hancock, Dawson R., and Bob Algozzine. 2006. Selecting a Design. In Doing Case Study Research: A Practical Guide for Beginning Researcher. New York: Teachers College Press, pp. 31-38. Available online: http://ir.obihiro.ac.jp/dspace/handle/10322/3933 (accessed on 14 March 2019).

Haque, Mohammed Ziaul, and Fara Azmat. 2015. Corporate Social Responsibility, Economic Globalization and Developing Countries: A Case Study of the Ready Made Garments Industry in Bangladesh. Sustainability Accounting, Management and Policy Journal 6: 166-89. [CrossRef]

Harvard T.H. CHAN School of Public Health. 2019. Conceptual Model I Center for Work, Health, \& Well-Being. September 30. Available online: http:/ / centerforworkhealth.sph.harvard.edu/research/conceptual-model (accessed on 21 March 2020).

Harvey, Ted, and Neil Gavigan. 2014. Minimizing Workplace Stress, Injuries and Violence in Canada: Towards a New Standard for Occupational Health and Safety (OHS). Toronto: SPR Associates Inc.

Heath, Rachel, and A. Mushfiq Mobarak. 2015. Manufacturing Growth and the Lives of Bangladeshi Women. Journal of Development Economics 115: 1-15. [CrossRef]

Hemphill, Thomas A., and George O. White. 2018. Multinational Enterprises, Employee Safety and the Socially Responsible Supply Chain: The Case of Bangladesh and the Apparel Industry. Business and Society Review 123: 489-528. [CrossRef] 
Huq, Fahian Anisul, Mark Stevenson, and Marta Zorzini. 2014. Social Sustainability in Developing Country Suppliers An Exploratory Study in the Ready Made Garments Industry of Bangladesh. International Journal of Operations E Production Management 34. [CrossRef]

ILO. 2017. The Rana Plaza Accident and Its Aftermath: Employment Injury Insurance and Protection. Available online: ilo.org/global/ topics /geip/WCMS_614394/lang--en/index.htm (accessed on 20 February 2019).

Istiak Ahmed Inam. 2019. Bangladesh Garment Workers Safer after Fire Trainings ISolidarity Center. Available online: https: / / www.solidaritycenter.org/bangladesh-garment-workers-safer-after-fire-trainings / (accessed on 17 June 2019).

Jacobs, Brian W., and Vinod R. Singhal. 2017. The Effect of the Rana Plaza Disaster on Shareholder Wealth of Retailers: Implications for Sourcing Strategies and Supply Chain Governance. Journal of Operations Management 49-51: 52-66. [CrossRef]

Labowitz, Sarah, and Dorotée Baumann-Pauly. 2014. Business as Usual Is Not an Option: Supply Chains and Sourcing after Rana Plaza. In Center for Business and Human Rights. New York: NYU Leonard N. Stern School of Business.

Labowitz, Sarah, and Dorothee Baumann-Pauly. 2015. Beyond the Tip of the Iceberg: Bangladesh's Forgotten Apparel Workers. Available online: http:/ / people.stern.nyu.edu/twadhwa/bangladesh/downloads/beyond_the_tip_of_the_iceberg_report.pdf (accessed on 25 July 2018).

Manu, Patrick, Abdul Majeed Mahamadu, Van Manh Phung, Thuan The Nguyen, Chandavid Ath, Abel Ying Teng Heng, and Soh Chuin Kit. 2018. Health and Safety Management Practices of Contractors in South East Asia: A Multi Country Study of Cambodia, Vietnam, and Malaysia. Safety Science 107: 188-201. [CrossRef]

Miles, Matthew B., and A. Michael Huberman. 1994. Qualitative Data Analysis, 2nd ed. Thousand Oaks: SAGE Publications, Inc. [CrossRef]

Morillas, Rosa María, Juan Carlos Rubio-Romero, and Alba Fuertes. 2013. A Comparative Analysis of Occupational Health and Safety Risk Prevention Practices in Sweden and Spain. Journal of Safety Research 47: 57-65. [CrossRef] [PubMed]

Nasrullah, Nakib Muhammad, and Mia Mahmudur Rahim. 2014. CSR in Private Enterprises in Developing Countries: Evidences from the Ready-Made Garments Industry in Bangladesh. Edited by Nakib Muhammad Nasrullah and Mia Mahmudur Rahim. Switzerland: Springer International Publishing. [CrossRef]

Nawaz, Waqas, Patrick Linke, and Muammer Koç. 2019. Safety and Sustainability Nexus: A Review and Appraisal. Journal of Cleaner Production 216: 74-87. [CrossRef]

Paul, Ruma, and Euan Rocha. 2017. Factbox: Major Industrial Accidents in Bangladesh in Recent Years. Reuters, July 4. Available online: https:/ / www.reuters.com/article/us-bangladesh-blast-accidents-factbox/factbox-major-industrial-accidents-inbangladesh-in-recent-years-idUSKBN19P0JN(accessed on 25 June 2019).

Prentice, Rebecca, Geert De Neve, Alessandra Mezzadri, and Kanchana N. Ruwanpura. 2018. Health and Safety in Garment Workers' Lives: Setting a New Research Agenda. Geoforum 88: 157-60. [CrossRef]

RCC. 2015. Remediation Coordination Cell for Bangladesh RMG Industry. Available online: http://rcc.dife.gov.bd/index.php/bn/ (accessed on 7 February 2019).

Robson, Lynda S., Benjamin C. Amick, Cindy Moser, Mark Pagell, Elizabeth Mansfield, Harry S. Shannon, Michael B. Swift, Sheilah Hogg-Johnson, Siobhan Cardoso, and Harriet South. 2016. Important Factors in Common among Organizations Making Large Improvement in OHS Performance: Results of an Exploratory Multiple Case Study. Safety Science 86: 211-27. [CrossRef]

Salminen, Jaakko. 2018. The Accord on Fire and Building Safety in Bangladesh: A New Paradigm for Limiting Buyers' Liability in Global Supply Chains? American Journal of Comparative Law 66: 411-51. [CrossRef]

Saunders, Mark, Philip Lewis, and Adrian Thornhill. 2016. Research Methods For Business Students. Research Methods For Business Students, 7th ed. Edinburgh Gate: Pearson.

Schüßler, Elke, Stephen Frenkel, Sarah Ashwin, Naila Kabeer, Niklas Egels-Zandén, Rachel Alexander, Lopita Huq, Chikako Oka, Nora Lohmeyer, Shahidur Rahman, and et al. 2019. Garment Supply Chains Since Rana Plaza:Governance and Worker Outcomes. Available online: www.wiwiss.fu-berlin.de/forschung/garments\%0AImage (accessed on 20 March 2020).

Serajul, Quadir. 2019. European Fashion Brands Agree New Deal in Bangladesh. Available online: https://mobile-reuters-com.cdn. ampproject.org/c/s/mobile.reuters.com/article/amp/idUSKCN1VO219 (accessed on 9 September 2019).

Siddiqi, Dina M. 2015. Starving for Justice: Bangladeshi Garment Workers in a 'Post-Rana Plaza' World. International Labor and Working-Class History 87: 165-73. [CrossRef]

Siddiqui, Javed, and Shahzad Uddin. 2016. Human Rights Disasters, Corporate Accountability and the State: Lessons Learned from Rana Plaza. Accounting, Auditing and Accountability Journal 29: 679-704. [CrossRef]

Sinkovics, Noemi, Samia Ferdous Hoque, and Rudolf R. Sinkovics. 2016. Rana Plaza Collapse Aftermath: Are CSR Compliance and Auditing Pressures Effective? Accounting, Auditing and Accountability Journal 29: 617-49. [CrossRef]

Solidarity Center. 2019. Fire and Other Safety Incidents in the Bangladesh Garment Sector. Available online: https://www. solidaritycenter.org/wp-content/uploads/2019/04/Bangladesh-2019-Safety-Incident-Chart.April-18-2019.pdf (accessed on 7 August 2019).

Sorensen, Glorian, Emily Sparer, Jessica A. R. Williams, Daniel Gundersen, Leslie I. Boden, Jack T. Dennerlein, Jeffrey N. Katz, Deborah L. McLellan, Cassandra A. Okechukwu, Nicolaas P. Pronk, and et al. 2019. Measuring Best Practices for Workplace Safety, Health and Wellbeing:The Workplace Integrated Safety and Health Assessment. Journal of Occupational and Environmental Medicine 60: 430-39. [CrossRef] 
Taplin, Ian M. 2014. Who Is to Blame?: A Re-Examination of Fast Fashion after the 2013 Factory Disaster in Bangladesh. Critical Perspectives on International Business 10: 72-83. [CrossRef]

Tebyetekerwa, Mike, Nicholus Tayari Akankwasa, and Ifra Marriam. 2017. The Current Working Conditions in Ugandan Apparel Assembly Plants. Safety and Health at Work 8: 378-85. [CrossRef] [PubMed]

The Daily Star. 2019. RMG Sustainability Council to Be Formed by Nov 25 I The Daily Star. Available online: https:/ / www.thedailystar. net/business/news/rmg-sustainability-council-be-formed-nov-25-1795234 (accessed on 20 September 2019).

Wadud, Zia, and Fuad Yasin Huda. 2017. Fire Safety in the Readymade Garment Sector in Bangladesh: Structural Inadequacy Versus Management Deficiency. Fire Technology 53: 793-814. [CrossRef]

Woodside, Arch G. 2010. Case Study Research: Theory, Methods and Practice. Los Angeles: Emerald.

World Health Organization. 2010. Healthy Workplaces: A Model for Action: For Employers, Workers, Policymakers and Practitioners. Geneva: World Health Organizations.

Yin, Robert K. 2009. Designing Case Studies. In Case Study Research Design and Methods, 3rd ed. Thousand Oaks: SAGE Publications, Inc., pp. 29-53. [CrossRef] 